This document was prepared in conjunction with work accomplished under Contract No. DE-AC09-96SR18500 with the U. S. Department of Energy.

\title{
DISCLAIMER
}

This report was prepared as an account of work sponsored by an agency of the United States Government. Neither the United States Government nor any agency thereof, nor any of their employees, makes any warranty, express or implied, or assumes any legal liability or responsibility for the accuracy, completeness, or usefulness of any information, apparatus, product or process disclosed, or represents that its use would not infringe privately owned rights. Reference herein to any specific commercial product, process or service by trade name, trademark, manufacturer, or otherwise does not necessarily constitute or imply its endorsement, recommendation, or favoring by the United States Government or any agency thereof. The views and opinions of authors expressed herein do not necessarily state or reflect those of the United States Government or any agency thereof.

This report has been reproduced directly from the best available copy.

Available for sale to the public, in paper, from: U.S. Department of Commerce, National Technical Information Service, 5285 Port Royal Road, Springfield, VA 22161, phone: (800) 553-6847, fax: (703) 605-6900

email: orders@ntis.fedworld.gov

online ordering: http://www.ntis.gov/help/index.asp

Available electronically at http://www.osti.gov/bridge

Available for a processing fee to U.S. Department of Energy and its contractors, in paper, from: U.S. Department of Energy, Office of Scientific and Technical Information, P.O. Box 62, Oak Ridge, TN 37831-0062,

phone: (865)576-8401,

fax: (865)576-5728

email: $\underline{\text { reports@ adonis.osti.gov }}$ 
United States Department of Energy

Savannah River Site

\section{Interim Measure/Interim Action Post-Construction Report (PCR) For The Old Radioactive Waste Burial Ground (643-E) (U)}

WSRC-RP-98-00721

Revision 1

April 1999

Prepared By:

Westinghouse Savannah River Company

Savannah River Company

Aiken, SC 29808

Prepared for the U. S. Department of Energy under Contract No. DE-AC09-96-SR18500 
Interim Measure/Interim Action PCR

WSRC-RP-98-00721

For The Old Radioactive Waste Burial Ground (643-E) (U)

Rev. 1

Savannah River Site

April 1999

This page was intentionally left blank. 
Interim Measure/Interim Action PCR

TABLE OF CONTENTS

SECTION

PAGE

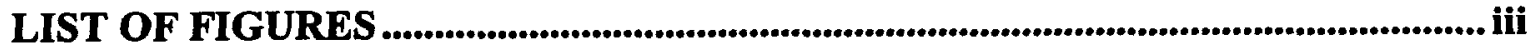

LIST OF ACRONYMS .......................................................................................................... iv

1.0 SYNOPSIS OF CONSTRUCTION WORK COMPLETED ...................................... 1

2.0 DEVIATIONS FROM ORIGINAL DESIGN.......................................................... 10

3.0 CERTIFICATIONS FOR THE INTERIM SOIL COVER................................. 13

4.0 VERIFICATIONS OF THE INTERIM SOIL COVER ........................................ 14

5.0 AS-BUILT DRAWINGS ............................................................................................... 15

6.0 REFERENCES................................................................................................................ 16

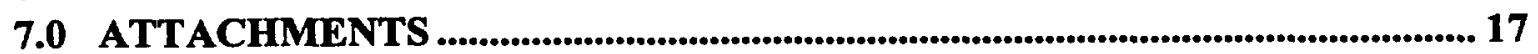

LIST OF FIGURES

FIGURE 1. OLD RADIOACTIVE WASTE BURIAL GROUND LAYOUT............ 4 


\section{LIST OF ACRONYMS}

BGC

CERCLA

CMP

EPA

ER

FFA

LLRWDF

ORWBG

RCRA

SCDHEC

SRS

WSRC
Burial Ground Complex

Comprehensive Environmental Response, Compensation and Liability Act

Corrugated Metal Pipe

Environmental Protection Agency

Environmental Restoration

Federal Facility Agreement

Low Level Radioactive Waste Disposal Facility

Old Radioactive Waste Burial Ground

Resource Conservation and Recovery Act

South Carolina Department of Health and Environmental Control

Savannah River Site

Westinghouse Savannah River Company 


\subsection{SYNOPSIS OF CONSTRUCTION WORK COMPLETED}

The Burial Ground Complex (BGC) occupies approximately 194 acres in the central part of Savannah River Site (SRS) in E-Area between the F and $\mathrm{H}$ Separations Areas. The BGC is divided into a northern area containing approximately 118 acres and a southern area containing approximately 76 acres. The southern area is the Old Radioactive Waste Burial Ground (ORWBG), 643-E, which consist of an earthen trench disposal area that began receiving waste in 1952 and was filled in 1972. This portion of the BGC is addressed by this interim measure/interim action.

In 1996, an interim measure/interim action was pursued for ORWBG as a source control measure to gain risk reduction before a final action is implemented. In May 1996 an Interim Record of Decision for this unit was approved by EPA and SCDHEC (Reference 6.3) which selected the placement of a soil cover as an interim action. In May 1996 the combined Interim Action Remedial Design/Remedial Action Work Plan/Remedial Design Report for the Old Radioactive Waste Burial Ground (643-E), which provided the design details of the soil cover, was approved by EPA and SCDHEC.

The soil cover provides a graded, low hydraulic conductivity barrier to decrease stormwater infiltration into the underlying waste, thereby reducing leachate production and contaminant transport to the groundwater. Decreased infiltration provides risk reduction for the ORWBG. Furthermore, the soil cover provides additional surface protection to reduce risk associated with contaminant runoff from stormwater. Although no formal effectiveness monitoring program is included as a part of this Interim Action, groundwater monitoring for the ORWBG area is currently ongoing under the BGC Field Investigative Plan (FIP) 
and the Mixed Waste Management Facility RCRA Part B Permit application, and will continue as part of those programs. This cover configuration does not preclude future remediation activities.

The interim soil cover extends over the ORWBG waste trenches for most of its 76 acres. Two main areas of the ORWBG remain uncovered by the interim soil cover: the existing SRS Solid Waste Operations administrative area and 22 inactive buried solvent tanks. Both of these uncovered areas are located near the center of the ORWBG. See Figure 1 for ORWBG layout. For construction purposes the cover was divided into eight sections lettered A through $\mathrm{H}$. The majority of soil came from two SRS borrow pits.

The soil cover system consists of a 24-inch compacted low hydraulic conductivity layer underlying a 6 inch vegetative layer, sloped to promote stormwater runoff. Compacted common backfill was used, where necessary, as a foundation for the low hydraulic conductivity layer. The hydraulic conductivity design criteria for the soil cover was $10^{-5} \mathrm{~cm} / \mathrm{sec}$. All soil placed was compacted to a minimum of 95\% of ASTM D698 at or above the optimum moisture content.

Prior to initiating construction for the soil cover, soil samples were collected from potential onsite borrow areas to determine the suitability of the material for use as a low hydraulic conductivity layer. The following laboratory tests were conducted on the soil samples:

- Compaction Tests (ASTM D698)

- Triaxial Tests (ASTM D2850)

- Grain Size Analyses (ASTM D421, D422, D1140) 
- Atterberg Limits \& Plasticity Index (ASTM D4318)

- Hydraulic Conductivity (ASTM D5084)

Grain size distribution and plasticity index parameters were correlated with the hydraulic conductivity results for the low hydraulic conductivity borrow source. These parameters were used to develop a soil specification for the low hydraulic conductivity layer that would correlate with the design value for hydraulic conductivity. Grain size distribution and plasticity index was selected as the parameters to control because they are easily measurable in the field. Additional design details of the soil cover are contained in Reference 6.2.

This interim measure/interim action complied with all federal and state requirements for erosion control and stormwater management. The stormwater management systems were upgraded to accommodate increased runoff due to the soil cover. The upgrades included installing or expanding three drainage ditches; installing concrete pipe, precast catch basins, and manholes; and constructing or expanding two sedimentation basins. The upgrades also included the installation of three new culverts under SRS Road E at each existing drainage ditch. The Southwest Basin dam was constructed of low permeable soils from the existing SRS Turner Road Borrow Pit. Spoils from the construction of the Southwest Basins were disposed in the Burma Road Landfill.

The construction of the interim soil cover was executed under a WSRC Basic Ordering Agreement (BOA) fixed price subcontract. The BOA consists of companies that have been prequalified to perform environmental remediation activities at SRS. WSRC's pre-bid estimate for the soil cover project in 1996 was $\$ 4.853 \mathrm{M}$; the BOA subcontract was executed for a final cost of $\$ 4.646 \mathrm{M}$. 


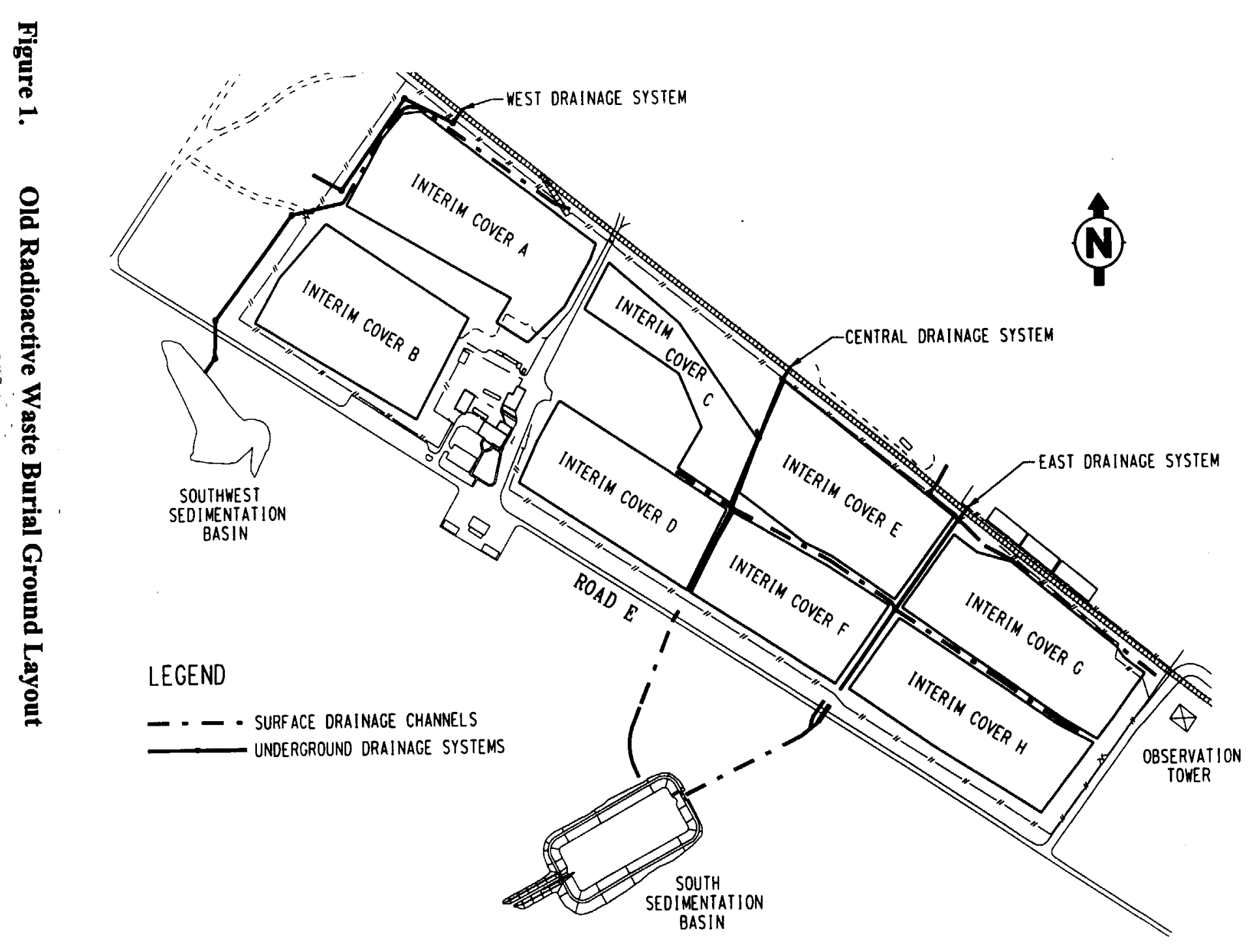

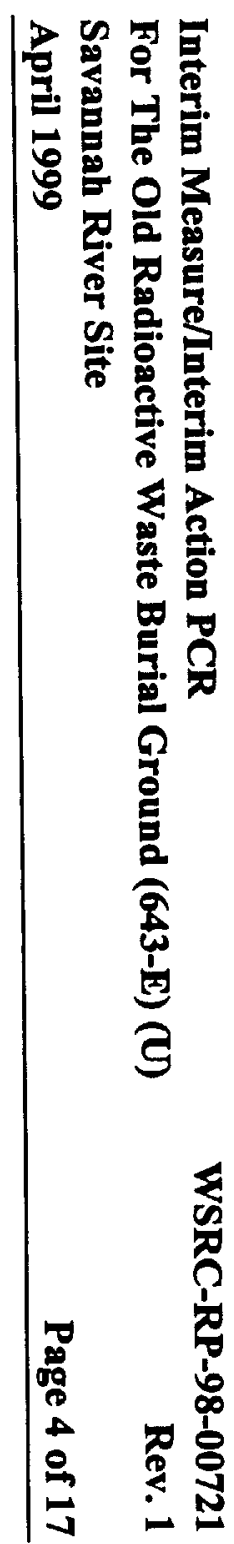


The following is a summary list of major construction events for the ORWBG Interim Soil Cover System.

\subsection{Construction of Sedimentation Basins}

The existing ORWBG stormwater management system was upgraded to manage the increased runoff created by the interim soil cover. The upgrade required construction of a new basin, the southwest sedimentation basin, located southwest of the ORWBG. Low hydraulic conductivity soil used for construction of the new sedimentation basin was hauled from the existing Turner Road borrow pit, located a few miles from the project site at SRS. The south sedimentation basin, an existing basin south of the ORWBG was expanded to manage additional runoff. These basins were sized to detain stormwater runoff at or below predevelopment levels for the 2-, 10-, and 25-year, 24-hour storm events.

The existing NPDES Industrial Storm Water General Permit (SCR-000000) covers all discharges from the Burial Ground Complex. As required by the permit, a Storm Water Pollution Prevention Plan was developed describing the industrial storm water discharges and the required monitoring as a land disposal facility. In addition, as specified by the permit the South Sedimentation Basin was rationalized to be representative of all storm water discharges from the Burial Ground Complex and semi-annual monitoring began in 1993. Upon completion of the South West Sedimentation Basin, the Pollution Prevention Plan was modified to include this discharge. However, monitoring of the South Sedimentation Basin discharge was still considered the most representative of the Burial Ground Complex. Currently, there are no established limits or standards for storm water discharges under the Clean Water Act NPDES program. 
However, the General Permit does require that the data be reviewed to determine an upward trend of storm water pollutants that would require mitigation.

Chronology:

\begin{tabular}{|l|l|}
\hline Start Date & Construction of Southwest and South Sedimentation Basins \\
\hline $7 / 18 / 96$ & $\begin{array}{l}\text { Began work on stormwater management system in accordance } \\
\text { with Stormwater Management and Sediment Control Plan and } \\
\text { Traffic Safety Plan }\end{array}$ \\
\hline $7 / 29 / 96$ & Surveyed southwest sedimentation basin. \\
\hline $8 / 8 / 96$ & Improved access road to Turner Road borrow pit. \\
\hline $8 / 14 / 96$ & Cleared and grubbed southwest sedimentation basin. \\
\hline $9 / 12 / 96$ & Excavated at southwest basin to construct a new basin. \\
\hline $9 / 16 / 96$ & Cleared and grubbed south basin. \\
\hline $9 / 26 / 96$ & Excavated at south basin to expand basin capacity. \\
\hline $10 / 29 / 96$ & Improved roadway at south basin \\
\hline $11 / 5 / 96$ & $\begin{array}{l}\text { Placed low permeable soil from Turner Road borrow pit at } \\
\text { southwest basin. }\end{array}$ \\
\hline $11 / 5 / 96$ & Placed low permeable soil in southwest basin. \\
\hline $11 / 12 / 96$ & Constructed overflow channel at southwest basin. \\
\hline $12 / 2 / 96$ & Performed hydro-seeding at southwest basin. \\
\hline $12 / 10 / 96$ & Performed hydro-seeding at south basin. \\
\hline & Work completed. \\
\hline
\end{tabular}

\subsection{Construction of West, Central, and East Drainage Systems}

Three existing drainage systems were upgraded to accommodate increased runoff from the soil cover for a 25-year, 24-hour storm event. All three systems now include concrete pipe, catch basins, and grass lined channels. The west drainage system directs stormwater to the new southwest sedimentation basin. Using the jack-and-bore method, a culvert was constructed under SRS Road E for the west drainage system. Culverts were also constructed using traditional methods beneath Road $\mathrm{E}$ for the central and east drainage systems. The central and east drainage systems convey stormwater to the expanded south sedimentation basin. Finally, a new asphalt channel was constructed to enhance stormwater flow from the central drainage system to the south basin. 


\begin{tabular}{|l|l|}
\hline Start Date & $\begin{array}{l}\text { Construction of West, Central, and East Stormwater } \\
\text { Systems }\end{array}$ \\
\hline $10 / 18 / 96$ & Located interferences along east drainage system. \\
\hline $10 / 18 / 96$ & Cut E Road for east drainage system. \\
\hline $10 / 19 / 96$ & $\begin{array}{l}\text { Installed } 60 \text {-inch CMP for E Road culvert for east drainage } \\
\text { system. }\end{array}$ \\
\hline $11 / 21 / 96$ & Paved asphalt channel for south sedimentation basin addition. \\
\hline $2 / 24 / 97$ & $\begin{array}{l}\text { Cleared and grubbed for west drainage system and stockpiled } \\
\text { piping. }\end{array}$ \\
\hline $4 / 3 / 97$ & Installed piping for west drainage system. \\
\hline $4 / 23 / 97$ & $\begin{array}{l}\text { Old comgated culvert encountered at west drainage system; } \\
\text { RadCon surveys indicated above-background levels of } \\
\text { radioactivity present. }\end{array}$ \\
\hline $5 / 14 / 97$ & Old culvert disposed under soil cover. \\
\hline $6 / 6 / 97$ & Cut E Road for central drainage system. \\
\hline $6 / 7 / 97$ & $\begin{array}{l}\text { Installed triple box culvert at E Road crossing for central } \\
\text { drainage system. }\end{array}$ \\
\hline & Work completed. \\
\hline
\end{tabular}

\subsection{Construction of Interim Soil Cover - Sections A through H}

The interim soil cover was divided into eight sections for construction purposes (see Figure 1). The soil cover is composed of three layers - a foundation layer of common backfill soils (where needed), a 2-foot layer of low hydraulic conductivity soil, and a six-inch vegetation layer composed of a mix of topsoil and common backfill (see Reference 6.2 for details). Prior to placing the foundation layer, the existing ground surface was proof-rolled using a vibratory roller to identify any sinkholes or potential areas of instability. Areas with depressions were subsequently leveled with soil and compacted. Test mats were constructed for the foundation layer and for the low hydraulic conductivity layer to demonstrate and verify the method of placement and compaction. Quality control testing was performed for soils placed throughout the project in accordance with the project specifications. Tests included gradation, moisture content, in-place density, and plasticity index (see Reference 6.2 for details). Areas failing the criteria established in the project specifications were reworked 
by SRS until the criteria were met. After placing the final layer of vegetative mix, it was seeded with a mixture of permanent and temporary grasses and fertilized.

A new borrow pit was developed specifically for this project to supply common fill soil for the interim soil cover. This pit, the East Borrow Pit, was constructed northeast of the ORWBG, just adjacent to SRS E-Area. Additionally, small amounts of common fill soil were occasionally made available from an adjacent WSRC Environmental Restoration project (the Low Level Radioactive Waste Disposal Facility project, a RCRA closure adjacent to the ORWBG).

Low hydraulic conductivity soil for the soil cover was hauled from the Central Shops Borrow Pit, located a few miles away from the ORWBG adjacent to the SRS Central Shops area. This pit was initially developed for the interim soil cover project, and is maintained by the SRS Central Services Works Engineering organization to supply soil to other SRS projects.

\begin{tabular}{|l|l|}
\hline Start Date & Construction of Interim Soil Cover \\
\hline $7 / 23 / 96$ & Mobilized subcontractor. \\
\hline $8 / 8 / 96$ & Surveyed East Borrow Pit. \\
\hline $8 / 12 / 96$ & Conducted pre-construction surveys of the ORWBG. \\
\hline $8 / 28 / 96$ & Developed East Borrow Pit. \\
\hline $9 / 17 / 96$ & $\begin{array}{l}\text { Pre-rolled east side of ORWBG for stockpiling of soil from } \\
\text { East Borrow Pit. }\end{array}$ \\
\hline $10 / 21 / 96$ & $\begin{array}{l}\text { Loaded and hauled soil for south basin and stockpiled in } \\
\text { ORWBG Sections G and H. }\end{array}$ \\
\hline $11 / 4 / 96$ & $\begin{array}{l}\text { Loaded and Hauled soil from East Borrow Pit and southwest } \\
\text { basin and stockpiled in ORWBG Sections G and H. }\end{array}$ \\
\hline $12 / 10 / 96$ & Stockpiled soil at Central Shops Borrow Pit. \\
\hline $12 / 16 / 96$ & Obtained soil samples for Central Shops Borrow Pit. \\
\hline $12 / 16 / 96$ & Pre-rolled Section E/F. \\
\hline $12 / 16 / 96$ & Pre-rolled Section G/H. \\
\hline $12 / 16 / 96$ & Pre-rolled Test Mat in Section H. \\
\hline $1 / 6 / 97$ & Unloaded and spread common fill at Section E/F. \\
\hline $1 / 6 / 97$ & Identified topography problem in Section C. \\
\hline $1 / 15 / 97$ & Loaded and hauled soil from Central Shops Borrow Pit. \\
\hline $1 / 17 / 97$ & Pre-rolled Section A. \\
\hline
\end{tabular}




\begin{tabular}{|c|c|}
\hline Start Date & Construction of Interim Soil Cover \\
\hline $1 / 20 / 97$ & $\begin{array}{l}\text { Unloaded and spread low permeable soil at Test Mat in } \\
\text { Section } \mathrm{H} \text {. }\end{array}$ \\
\hline $1 / 23 / 97$ & $\begin{array}{l}\text { Unloaded and spread common fill from LLRWDF at Section } \\
\text { A }\end{array}$ \\
\hline $1 / 31 / 97$ & Unloaded and spread low permeable soil at Section G/H. \\
\hline $2 / 1 / 97$ & Unloaded and spread common fill at Section G/H. \\
\hline $3 / 24 / 97$ & Unloaded and spread low permeable soil at Section E/F. \\
\hline $4 / 1 / 97$ & Pre-rolled Section C. \\
\hline $4 / 1 / 97$ & Unloaded and spread low permeable soil at Section D. \\
\hline $4 / 1 / 97$ & $\begin{array}{l}\text { Unloaded and spread mixture of topsoil and common fill at } \\
\text { Section } \mathrm{G} / \mathrm{H} \text {. }\end{array}$ \\
\hline $4 / 2 / 97$ & Pre-rolled Section B. \\
\hline $4 / 24 / 97$ & Unloaded and spread common fill at Section B. \\
\hline $5 / 24 / 97$ & Pre-rolled Section D. \\
\hline $6 / 4 / 97$ & Unloaded and spread common fill at Section D. \\
\hline $6 / 24 / 97$ & Unloaded and spread low permeable soil at Section A \\
\hline $6 / 24 / 97$ & Unloaded and spread low permeable soil at Section B. \\
\hline $7 / 1 / 97$ & $\begin{array}{l}\text { Unloaded and spread mixture of topsoil and common fill at } \\
\text { Section A }\end{array}$ \\
\hline $7 / 1 / 97$ & $\begin{array}{l}\text { Unloaded and spread mixture of topsoil and common fill at } \\
\text { Section B. }\end{array}$ \\
\hline $7 / 1 / 97$ & $\begin{array}{l}\text { Unloaded and spread mixture of topsoil and common fill at } \\
\text { Section D. }\end{array}$ \\
\hline $7 / 1 / 97$ & $\begin{array}{l}\text { Unloaded and spread mixture of topsoil and common fill at } \\
\text { Section E/F. }\end{array}$ \\
\hline $7 / 1 / 97$ & $\begin{array}{l}\text { Unloaded and spread common fill at Section } \mathrm{C} \text { for redesigned } \\
\text { cap. }\end{array}$ \\
\hline $8 / 1 / 97$ & Unloaded and spread low permeable soil at Section C. \\
\hline $10 / 1 / 97$ & $\begin{array}{l}\text { Unloaded and spread mixture of topsoil and common fill at } \\
\text { Section C. }\end{array}$ \\
\hline $10 / 1 / 97$ & Closed and seeded East Borrow Pit. \\
\hline $1 / 1 / 98$ & $\begin{array}{l}\text { Conducted turnover walkdown for mechanical completion of } \\
\text { project and generated punchlist items. }\end{array}$ \\
\hline $2 / 1 / 98$ & $\begin{array}{l}\text { Completed punchlist items. Completed cleaning of new } \\
\text { piping systems. Notified SCDHEC and EPA of project } \\
\text { completion. }\end{array}$ \\
\hline $5 / 19 / 98$ & SCDHEC Field Inspection/Visit of the completed soil cover. \\
\hline
\end{tabular}




\subsection{DEVIATIONS FROM ORIGINAL DESIGN}

The project successfully constructed the soil cover to encompass the waste trench areas in accordance with the Interim Action Remedial Design/Remedial Action Work Plan/Remedial Design Report for the Old Radioactive Waste Burial Ground (643-E) (Reference 6.2). No major configuration changes were required for the soil cover project, although several minor design changes were implemented.

A 25-foot survey grid pattern was used throughout the project to establish and maintain earthwork control points. This was a tighter grid pattern than the 100-foot pattern used for the design topographic survey. As expected, the project subcontractor encountered some survey anomalies. The project engineering team evaluated each anomaly on a case basis and design modifications were made accordingly. Most of the areas confined within a single 25-foot grid were not redesigned. For some of these areas, there is potential for small localized spots where the thickness of the low permeability layer is less than two feet. These small areas are judged to be insignificant to the mass permeability of the soil cover because:

- These areas, which have approximately $1.33^{\prime}$ to $1.5^{\prime}$ of low permeability cover, comprise no more than $1 \%-2 \%$ of the total area of the soil cover.

- The total depth of compacted backfill at most of these areas is 4 feet or greater since a foundation layer of common fill was used. The common fill soil used for the project was also native sandy clay that originated from a different source (East Borrow Pit) than the low hydraulic conductivity soil. 
Larger discrepant areas were redesigned to maintain the minimum 2-foot low permeability cover by changing the slope of the cover (maintaining a $3 \%-5 \%$ design range) or by a total redesign with new contours and control points.

Additionally, some areas of the soil cover required redesign to further minimize intrusive work in the ORWBG and to incorporate additional areas in which radioactive debris was discovered during construction. The following summarizes of the design changes made to the soil cover and drainage systems during construction:

- $\quad$ Cap A: No changes required.

- $\quad$ Cap B: Because of differences between actual topography and the design survey along the northern cap boundary, the cap was extended to the north in order to maintain the design slope and minimum thickness of the low permeability layer.

- $\quad$ Cap C: SRS encountered differences between the actual topography and the design survey in the area of Cap C north of the ORWBG Solvent Tanks. A section of the ORWBG had received additional fill from SRS Solid Waste Operations over the years, resulting in a localized mound. This condition was not reflected in the original design. Cap $\mathrm{C}$ was redesigned to maintain the minimum thickness of the low permeability layer over this area. The redesign maintained the cap slopes within the design criteria range specified in Reference 6.2.

- $\quad$ Cap D: No changes required.

- Cap E: No changes required. 
- Cap F: SRS discovered that the actual field topography in the southeast corner of Cap F (adjacent to the existing east drainage ditch) was slightly flatter than indicated on the design survey. This resulted in a redesign of this portion of Cap F to maintain the design minimum thickness of the low permeability layer. The redesign maintained the cap slopes within the design criteria range specified in Reference 6.2.

- Cap G: The original design required excavation on the north side of Cap $G$ in the area of the abandoned railroad spur embankment. Prior to commencing the excavation, SRS discovered radioactive soil beneath the surface at this location. This portion of Cap $G$ was subsequently redesigned by extending it northward to completely cover the old railroad embankment with a two-foot thick low permeability soil layer.

Cap H: Similar to Cap F, the actual field topography in the southwest comer of Cap $\mathrm{H}$ differed from the design survey. This portion of Cap $\mathrm{H}$ was redesigned to maintain the design minimum thickness of the low permeability layer. The redesign maintained the cap slopes within the design criteria range specified in Reference 6.2.

- West Stormwater Drainage System: An asphalt apron was added at the entry of the flared end section of the new west stormwater drainage system to minimize erosion adjacent to the southwest corner of Cap A.

- Central Stormwater Drainage System: The original design location of the new reinforced-concrete piping sections for the central stormwater drainage system required excavation into the existing drainage ditch sidewalls. To minimize this excavation, the piping sections were realigned to more closely match the centerline of the existing ditch. 
- East Stormwater Drainage System: The reinforced-concrete piping sections were realigned in a manner similar to that used for the Central Stormwater Drainage System to minimize excavation into the existing ditch sidewalls.

\subsection{CERTIFICATIONS FOR THE INTERIM SOIL COVER}

As a CERCLA Interim measure/interim action, the ORWBG requires no official certifications for project closeout. However, the following observations are noted:

- The primary objective of the soil cover was to reduce stormwater infiltration through the ORWBG waste trenches. To accomplish this objective, a hydraulic conductivity design value of $10^{-5} \mathrm{~cm} / \mathrm{sec}$ was selected for the 24 " low permeability layer.

- The borrow source for the low permeability layer was pre-qualified by performing soil testing (including permeability tests) prior to construction. The project engineering team used these test results to develop a soil specification for the low permeability layer that was based on grain size distribution and plasticity index. The subcontractor performed testing at the borrow site and at the soil cover to ensure compliance with the soil specification. SRS project construction and QA personnel provided oversight during construction (refer to Attachment 7.2 for a summary assessment of the project).

- Visual evidence indicates that stormwater runoff from the ORWBG has increased significantly since the soil cover was completed.

Accordingly, the ORWBG soil cover has met its performance standard. 


\subsection{VERIFICATIONS OF THE INTERIM SOIL COVER}

Specific quality assurance requirements were incorporated into the project construction specifications for the interim soil cover. For example, the project subcontractor was required to make the following submittals:

- A project testing and inspection plan.

- Testing laboratory and personnel qualifications.

- Fabrication drawings for precast concrete structures and concrete reinforcement.

- Concrete mix designs.

- All soil and concrete test results.

These submittals are part of the permanent project file and are maintained as records by SRS. A summary assessment of the project's implementation of quality assurance requirements has been included as Attachment 7.2 of this Post Construction Report.

The SRS Environmental Restoration (ER) Operations Department assumed custodianship of the ORWBG soil cover and began regular maintenance inspections. Using a formal inspection process, trained personnel perform routine inspections to assess the condition of the soil cover every month and after major storms. Items examined during these inspections typically include:

- Verifying access to the soil cover.

- Checking all fences, barricades, and postings for the soil cover. 
- Checking for excess vegetation obscuring signs and postings or blocking storm drains.

- Checking all drainage ditches for debris which may restrict flow.

- Checking for eroding areas, any uncovered buried waste, or abnormal soil cracks.

- Visually checking for depressions greater than $12 "$.

- Visually check vegetative cover for adequacy.

The results of these inspections are documented on data sheets and maintained as records.

Maintenance of the soil cover (e.g., repair as a result of erosion, subsidence, burrowing animals, vehicular activity, etc.) will be coordinated by ERD Operations. ERD Operations will also continue inspections and maintenance as required by the Stormwater Management and Sediment Control Plan/Pollution Prevention Plan for the ORWBG until permanent vegetation is established.

SRS and SCDHEC personnel conducted two formal walkdowns of the soil cover in May 1998 and September 1998. SCDHEC found the soil cover to be acceptable. SCDHEC comments from the walkdowns, along with SRS comment responses, are included as an attachment to this post-construction report (Attachment 7.1).

\subsection{AS-BUILT DRAWINGS}

5.1 Site Vicinity and Area Maps, General Notes and Drawing Index (U) 
Interim Measure/Interim Action PCR

WSRC-RP-98-00721

For The Old Radioactive Waste Burial Ground (643-E) (U)

Rev. 1

Savannah River Site

April 1999

Page 16 of 17

5.2 Grading Plan - East Area (U)

5.3 Grading Plan - West Area (U)

5.4 Southwest Basin Stormwater Management and Sediment Control Grading, Sections and Details (U)

5.5 Drainage Layout - East Plan (U)

5.6 Drainage Layout - West Plan (U)

5.7. Outfall Plan and Drainage Structures Details 60-inch RCP and 60-inch CMP (U)

5.8 Outfall Plan and Structural Details for $4 \mathrm{ft} \times 2 \mathrm{ft}$ Box Culverts

5.9 Storm Drain Profiles (U)

5.10 Sections and Details (U)

5.11 South Sedimentation Basin Maintenance and Improvements Plan View (U)

5.12 South Sedimentation Basin Maintenance and Improvements Sections (U)

\subsection{REFERENCES}

6.1 WSRC, 1995, Interim Action Proposed Plan for the Old Radioactive Waste Burial Ground (643-E)(U), WSRC-RP-1125, Rev. 1, December, Westinghouse Savannah River Company, Aiken, SC 29802. 
6.2 WSRC, 1996a, Interim Action Remedial Design / Remedial Action Work Plan/ Remedial Design Report for the Old Radioactive Waste Burial Ground (643-E) (U), WSRC-RP-96-113, Revision 1, May, Westinghouse Savannah River Company, Aiken, SC 29802.

6.3 WSRC, 1996b, Interim Record of Decision - Remedial Alternative Selection for the Old Radioactive Waste Burial Ground (643-E) (U), WSRC-RP-96-102, Rev. 0, March, Westinghouse Savannah River Company, Aiken, SC 29802.

\subsection{ATTACHMENTS}

7.1 SCDHEC Comments from Walkdown with SRS Responses

7.2 WSRC-RP-98-4197, "Summary Assessment of the Old Burial Ground Interim Action Soil Cover Construction" 
Interim Measure/Interim Action PCR

WSRC-RP-98-00721

For The Old Radioactive Waste Burial Ground (643-E) (U)

Rev. 1

Savannah River Site

Attachments

April 1999

Page 1 of 7

\section{ATTACHMENT 7.1}

SCDHEC Comments from 5/19/98 Walkdown with SRS

Responses

SCDHEC Observations from 9/17/98 Walkdown 
Interim Measure/Interim Action PCR

For The Old Radioactive Waste Burial Ground (643-E) (U)

Savannah River Site

April 1999
WSRC-RP-98-00721

Rev. 1

Attachments

Page 2 of 7

Response to SCDHEC May 1998 Concerns on the May 19, 1998, Field Inspection/Visit for the Completion of the Interim Action/Interim Measures (Soil Cover) at the Old Radioactive Waste Burial Ground (643-E) (ORWBG)

Comment 1. The vegetative cover over a majority of the ORWBG was inadequate. It appeared as though the vegetative cover had not been properly seeded or germinated and was not green and alive. The SRS stated that they were currently working with the contractor to take necessary actions to improve the vegetative portion of the interim soil cover to satisfactory level. In its current condition, it is likely with heavy rainfall that some erosion in various areas within the ORWBG will occur. It was evident that erosion had already occurred in various areas due to the lack of proper vegetative cover.

Response 1: South Carolina Department of Health and Environmental Control's (SCDHEC) visit occurred at a time when the temporary winter vegetative cover was experiencing seasonal die-off. A majority of the soil cover received permanent grass seed in the fall and is only now germinating. Since SCDHEC's visit, several areas were re-seeded and/or fertilized. This summer's drought and the absence of an irrigation system have impeded our ability to establish a permanent cover. However, recent rains provided some relief and permanent grass is beginning to germinate. SRS also enlisted the United States Forestry Service (USFS) in our efforts. The USFS recommended that SRS should apply additional ammonium nitrate fertilizer to the soil cover to accelerate the growth of the permanent Bermuda grass. Additionally, they recommended against any further reseeding with temporary grasses. SRS is implementing these recommendations. SRS is also re-evaluating the existing the existing cover maintenance and inspection program to effect more preventative erosion controls.

Comment 2. Two storm water drains inlets located in the North Central portion of the ORWBG were blocked and obstructed with silt and sediment buildup. One inlet was completely blocked and standing water in the immediate vicinity of this storm water drain inlet had resulted. The other storm water drain inlet was partially open, but had a significant blockage due to silt and sediment accumulation. The temporary silt fencing surrounding these two storm water drain inlets was in poor condition and needed repair or replacement.

Response 2: These items were corrected and SRS is conducting routine erosion control inspections to monitor soil cover and drainage system conditions.

Comment 3. The drainage ditch surrounding the southwest portion of the ORWBG was in poor condition. The drainage ditch was full of silt and sediment that had flowed from the interim soil cover due to erosion. This erosion most probably occurred due to the lack of adequate vegetative soil cover in the areas that had eroded. The drainage ditch should 
Interim Measure/Interim Action PCR

WSRC-RP-98-00721

For The Old Radioactive Waste Burial Ground (643-E) (U)

Rev. 1

Savannah River Site

Attachments

April 1999

Page 3 of 7

be cleaned out and the material placed back on the interim soil cover from the areas where it originated.

Response 3: Drainage for the soil cover in this area is designed to sheet flow through the chain link fence to the ditch along Road E. At the time of SCDHEC's visit, silt fences installed along the chain link fence had accumulated silt that washed off the soil cover during the winter rains. The area was repaired and SRS is conducting regular erosion control inspections to monitor future conditions.

Comment 4. Stacked creosote treated railroad crossties were noted in two locations in the northeastern portion of the ORWBG. Multiple crossties were observed uncovered and stacked on the flatbed trailers in the "wetland" area located in the central northeastern portion and crossties were also noted beyond the fenced perimeter in the northeastern portion as well. There is a concern that leaching of creosote related contaminants (i.e. BTEX and PAHs) and radionuclides, due to infiltration of rainfall, is potentially contributing to contamination in the "wetland" area and possibly emanating down gradient from the ORWBG through the stormwater management systems.

Several outfall stations in the vicinity of the ORWBG are being monitored as part of the NPDES program. Are BTEX, PAHs or other related contaminants being monitored as part of the NPDES program?

SRS should plan for the removal/burial and appropriate disposal of the crossties from the ORWBG. The Department would like SRS to propose a strategy(s) to SCDHEC and EPA to address the problem.

Response 4: Presently, this area is not officially delineated as a wetland in accordance with 10 CFR 1022. This areas affords many characteristics of a wetland, therefore, SRS will manage this area as a wetland until the formal delineation process is completed. The crossties and wooden barricades currently stored on flatbed trailers in this area will be removed from the area and disposed of in an approved disposal facility consistent with SRS procedures.' The drainage from this area is directed to a stormwater retention basin that is sampled twice per year for parameters specified in Part VI.B.2.c. of the NPDES General Permit for Stormwater Discharges Associated With Industrial Discharges (SCR000000). Further, per Part VI.B.8 of that permit, additional parameters believed to be present are monitored. These include phenol and VOA analyses, which would indicate if any pollutants from the crossties were reaching the outfall. Additional samples are taken for radionuclides on a regular basis and the results published in the site Annual Environmental Report. The crossties have been added to the Pollution Prevention Plan for this area. 
Based on many years of sampling data it has been shown that old railroad crossties and telephone poles are not hazardous in terms of waste. There is a possibility for the crossties and poles contain low levels of radioactive contamination. Since it is difficult for the crossties and poles to be radioactively screened, they will likely be treated as suspect low-level radioactive waste. SRS is currently working on disposal options for this material.

Comment 5. Multiple narrow erosion "ruts/rills", approximately one (1) foot wide, 7 to 10 inches deep, were observed in the western area of the ORWBG, most notably in the northwestern portion. Most erosional features ran perpendicular to the central stormwater drainage feature at approximately every 30-40 feet. Please address this problem and develop the cover system in order to minimize soil cover system erosion in this area.

Response 5: Although the areas noted have been repaired, erosion control and repair of rills will be an ongoing issue for the ORWBG soil cover until a permanent vegetative cover is established. SRS will repair all rills and conduct regular erosion control inspections to identify any areas in further need of repair.

Comment 6. One of the objectives of the Interim Soil Cover system as stated in the Interim RD/RA Report was to prevent runoff from entering the ORWBG Solvent Tank area. However, it appears that there is no drainage mechanism in place, other that silt fencing, in order to divert the stormwater runoff from flowing directly into the area containing the solvent tanks. Please address the need for additional drainage enhancement in order to meet one of the minimum requirements of the soil cover system in that area.

Response 6: The design of the ORWBG Interim Soil Cover in the Solvent Tank area is for stormwater to sheet flow away from the area (refer to design drawings submitted with WSRC-RP-96-113, "Interim Action Remedial Design/Remedial Action Work Plan/Remedial Design Report for the Old Radioactive Waste Burial Ground"). Throughout the heavy rains of last winter, the soil cover in this area performed as expected, and water did not enter the Solvent Tank area. Localized ponding of stormwater does tend to occur at the northeast corner of the Solvent Tank area during heavy rains but has not entered the controlled radiological zone around the tanks. Further fill and grading in this area is currently being planned by SRS as maintenance actions this fall to eliminate this condition. 


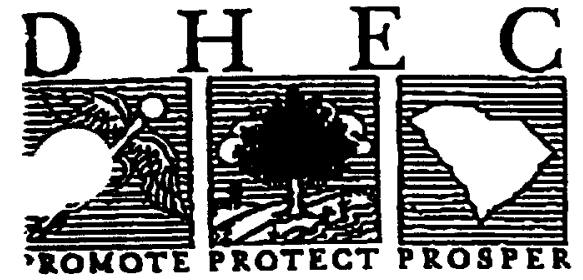

1600 Bull Street

Solumbir, SC 29201-1708

October 7, 1998

\section{CERTIEIED MAT}

Mr. Brian T. Hennessey, Project Manager

Environmental Restoration Division

U. S. Department of Energy

Savannah River Operations Office

P. O. Box A

Aiken, South Carolina 29802

RE: Field Inspection/Visit for the Completion of the Interin Action/Interim Measure (Soil Cover) at the Old Radioactive Waste Burial Ground (643-E) (ORWBG), dated September 171998.

Dear Mr. Hennessey:

An inspection of the interim low hydraulic conductivity soil cover system placed over the ORWBG as an interim action/interim measure was conducted on September 17, 1998 with representatives from the SCDHEC and the SRS present. Representatives from the SCDHEC were Julie Elam, Alan Coffey, Roger Schweitzer and Mihir Mehta. The inspection started at approximately 11:00am and ended around 1:00pm. The weather was clear and the temperature was warm at approximately $80-85$ degree's $F$. As a result of the inspection, the following observations were noted.

If you should have any questions, please contact me at 896-4055.

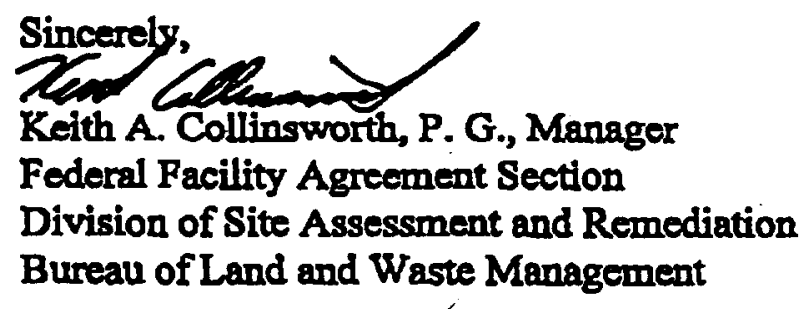

cc: Myra Reece, Lower Savannah Jeff Crane, EPA Region IV

R. Kim Cauthen, WSRC (signed original)

A. Ben Gould, DOE 
South Carolina Department of Health and Environmental Control Comments/discrepancies on: Field Inspection/Visit for the Completion of the Interim Action/nterim Measure (Soil Cover) at the Old Radioactive Waste Burial Ground (643-E) (ORWBG), dated September 171998.

1. The vegetative cover was greatly improved in the entire eastern and western potion of the ORWBG in comparison to observations made during the initial May 19, 1998 field inspection/visit.

The crosion "ruts/rills" observed in the western area during the May 19, 1998 field inspection/visit appeared to be reduced as a result of the substantial improvement to the vegetative layer. Monthly maintenance of the soil cap should include on-going improvements of these erosional features to ensure optimization of the ORWBG soil cover.

2. The Department noted a significant improvement at the drainage ditch surrounding the southwest portion of the ORWBG adjacent to the parking area. The ditch had been cleaned out, vegetation was growing, and new silt fencing emplaced along the perimeter.

3. The stomwater drainage inlet located in the center of both eastern and western most portion of the ORWBG showed moderate erosion. Measures should be taken in order to minimize erosion in this area and the vegetation around the stormwater drainage inlets should be periodically trimmed to avoid clogging.

4. Sporadic portions of the soil cap were still without a vegetative cover most notably the side slopes along the center stormwater drainage feature. Please address this problem in order to minimize soil cover erosion in this area.

5. The Department noted that the railroad ties were placed at the eastern portion of the ORWBG. The Department would like to be notified of any change in the status or disposal activities associated with the railroad ties. 
Interim Measure/Interim Action PCR

For The Old Radioactive Waste Burial Ground (643-E) (U)

Savannah River Site

April 1999
WSRC-RP-98-00721

Rev. 1

Attachments

Page 7 of 7

\section{ATTACHMENT 7.2}

WSRC-RP-98-4197 Rev. 0, "Summary Assessment of the Old Burial Ground Interim Action Soil Cover Construction" 
WSRC-RP-98-4197 Rev 0

November 18, 1998

\title{
SUMMMARY ASSESSMENT OF THE \\ OLD BURIAL GROUND \\ INTERIM ACTION \\ SOIL COVER CONSTRUCTION
}

\begin{abstract}
Assessor: $\quad M$. Johns
\end{abstract}
Date: November 6, 1998

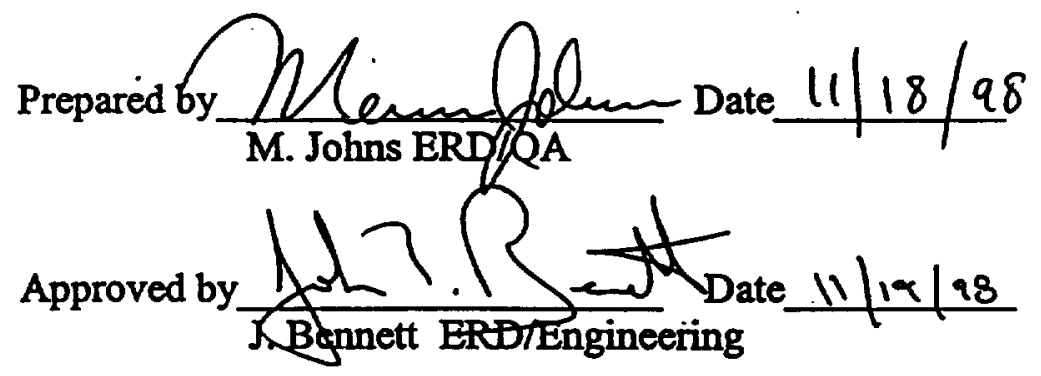


Executive Summary:

The soil cover system consists of a 24 inch compacted low hydraulic conductivity layer underlying a 6 inch vegetative layer, graded to promote runoff. Compacted common backfill was used, where necessary, as a foundation for the low hydraulic conductivity layer. The hydraulic conductivity design criteria for the soil cover was $10^{-5} \mathrm{~cm} / \mathrm{sec}$. All soil placed was compacted to a minimum of $95 \%$ of ASTM D698.

The EPA Technical Guidance Document "Quality Assurance and Quality Control for Waste Containment Facilities" EPA/600/R-93/182 Sept 1993 was followed for this project and found to be very useful.

\section{Purpose:}

The purpose of this summary assessment is to compile activities that were performed to achieve:

1. The required quality standard during the Old Burial Ground Interim Action Soil Cover evolution.

2. To list relevant documentation pertaining to the subcontractor's implementation of the interim soil cover project's requirements.

\section{Reference Documents :}

1. Interim Action Proposed Plan for the Old Burial Ground

2. "Summary of E-Area Borrow Pit Study for use in LLRWDF and Old Burial Ground Cover Systems", Walt Rabe Jan 16, 1996

3. Central Shops Borrow Source Analytical Data Sept 24, 1996

4. Central Shops Borrow site evaluation memo, John Bennett, May 5, 1996

5. Construction Procurement Specification "Old Radioactive Waste Burial Ground Interim Soil Cover" C-SPP-E-00010 Rev 0 Feb 27, 1996

6. "Contractor Construction Work Procedure" Sevensen Environmental Services, Inc. Feb 12, 1997 Rev 2

7. "Projeet Construction and QA plan" Sevensen Environmental Services, Aug 17, 1996

8. WSRC ERD/QA Quality Monitoring Reports

9. "CSRA Laboratory and Personnel Qualifications" CSRA Testing and Engineering Co., Inc., Aug 19, 1996

10. WSRC ERD/QA “CSRA Laboratory evaluation" March 1996

11. "Contractor Soil Test Result Data" Sevensen Environmental Services, May 26, 1998

\section{Summary:}

The following is a summary by category of items relating to the iterim soil cover.

1) The Interim Action Proposed Plan low permeability cover requirements were used as the design basis by Design Engineering to develop the construction specification. 
WSRC-RP-98-4197 Rev 0

November 18, 1998

2) The construction specification, C-SPP-E-00010 Rev 0 Feb 27, 1996, for the "Old Radioactive Waste Burial Ground Interim Soil Cover" includes numerous Quality requirements. Significant quality items were:

Specification Section 1.05 "Testing/Inspection Requirements"

A. Borrow Area Testing

Prior to hauling any soil to the project site, the following tests shall be performed to confirm that soil meets the specified acceptance criteria.

- Particle - size analysis of soils per ASTM D422

Sieve Size Percent Passing by Weight

No. $4 \quad 99-100$

No. $10 \quad 95-100$

No. $40 \quad 35-90$

No. $200>35$

- Laboratory compaction characteristics of soils per ASTM D698 Minimum 95 percent

- Liquid limit of soils per ASTM D4318

- Water (moisture) content of soil per ASTM D2216 or D4643

Low perm soil shall be placed at plus 3 percent to minus 1 percent optimum moisture

- Plastic Limit and Plasticity Index of soil per ASTM D4318

Minimum plasticity index shall be 15

All tests were performed satisfactorily by the contractor.

B. In-place Tests

Testing of compacted soil will be in accordance with ASTM D2922 or ASTM

D1556. If nuclear test instrumentation is used, calibration will be performed in accordance with ASTM D2922 and ASTM D3017. Additionally, for the first ten nuclear density tests, a sand cone test will be performed to establish a site specific relationship and one sand cone test every ten nuclear tests thereafter.

Nuclear density tests were performed by the contractor for compaction tests. Results were forwarded daily to WSRC with satisfactory results and a final documentation submittal was made at the completion of the work.

C. Acceptance Methods

All work will be inspected for conformance to project drawings and specification requirements with results recorded in an inspection report with the following items:

- Proper selection of fill material

- In-place density, moisture content; plasticity index, liquid limit and percent compaction of the compacted material

- Excavation and grading within specified tolerances 
- Frequency of testing and acceptability of test results

The contractor submitted daily log reports which included results of the above listed items.

D. Work Execution

- Prior to placing low permeability soil, a test pad of 100 feet square will be constructed to ensure that the procedure will produce the required compaction.

- Low permeability soil will be placed in layers not exceeding 12 inches.

- Placed soil will be conditioned, if necessary to meet the specified moisture content (plus or minus 3 percent from optimum moisture content).

- A layer will be compacted with 5 passes of a vibratory roller having a minimum dynamic force of 30,000 pounds per drum.

- Compacted layers will meet a minimum of 95 percent of ASTM D698.

- No successive layer will be placed until the compaction requirements of the previous layer have been met.

- The contact surface of the previous layer will be scarified to a minimum depth of 2 inches to ensure proper bonding between layers.

These items were routinely monitored by WSRC and deficiencies identified and corrected where necessary.

E. Contractor submittals are outlined in the Engineering Document Requirements attachment A and the Quality Verification Document Requirements attachment B. Included in the submittals were the following:

- Submittal of the contractors Construction Work Procedure

- Submittal of the contractors Quality Control Plan

- Submittal of the contractors Testing and Inspection Plan

- Submittal of the contractors Testing laboratory Qualifications (The testing laboratory is required to comply with ASTM 3740 and ASTM 329)

- Submittal of soil test results

These submittals were made by the contractor, comments were generated by WSRC and resolved with the contractor. The submittals are part of the permanent project file and are maintained as records by SRS.

3) Regarding borrow source preparation for the start of the interim soil cover construction, Environmental Restoration Department employed Site Geotechnical Services to perform an evaluation of three potential borrow sources. Prior to initiating construction for the soil cover, soil samples were collected from potential onsite borrow areas to determine the suitability of the material for use as a low hydraulic conductivity layer. - The following laboratory tests were conducted on the soil samples: 
- Compaction Tests (ASTM D698)

- Triaxial Tests (ASTM D2850)

- Grain Size Analyses (ASTM D421, D422, D1 140)

- Atterberg Limits \& Plasticity Index (ASTM D4318)

- Hydraulic Conductivity (ASTM D5084)

The results of the investigation were that a further soil source would be needed to fulfill project requirements.

The borrow site at the Central Shops area was identified and a complete series of laboratory tests performed which indicated acceptability of this source. These test data are maintained in the project file. The Central Shops borrow source was subsequently used as the primary source for low permeability soil for this project.

Grain size distribution and plasticity index parameters were correlated with the hydraulic conductivity results for the low hydraulic conductivity borrow source. These parameters were used to develop a soil specification for the low hydraulic conductivity layer that would correlate with the design value for hydraulic conductivity. Grain size distribution and plasticity index were selected as the parameters to control because they are easily measurable in the field.

4) WSRC Environmental Restoration Quality Assurance has performed various activities during the progression of the Old Burial Ground Interim Action. The following is a listing of the highlights:

- Review of the IAPP satisfactorily.

- Review and comment resolution of contractor procedure submittals. Subsequent QA monitoring to ensure contractor compliance with approved procedures.

- An evaluation of the CSRA laboratory was performed by ER QA. Several deficiencies were noted and resolved with a return visit. A further visit was performed to witness each of the borrow soil source tests performed by the laboratory with satisfactory results.

- ER QA attended and participated in weekly contractor construction status meetings during the entire construction of the interim soil cover during which Quality items were identified, discussed and resolved.

- ER QA regularly performed visits to the jobsite to verify satisfactory performance by the contractor. Significant items or items requiring resolution were recorded with a Quality Monitoring Report. The Quality monitoring reports are on file and include:

- Numerous compaction tests performed by CSRA laboratory with Troxler nuclear density instruments were witnessed satisfactorily. Sand cone tests were also witnessed satisfactorily. In addition, the contractor was found to maintain a $\log$ of density tests performed along with recorded locations. Logs 
were also maintained by the contractor for borrow soil tests as conditions changed.

- A deficient item was identified regarding contractors daily control of the quality of the soil during excavation, i.e. monitoring for a change in color, texture, or debris. It was agreed with the contractor that an experienced soils personnel will be responsible for daily monitoring the quality of the soil excavation at the borrow source.

- A deficient item was identified regarding unsatisfactory scarifying between low perm soil layers utilizing bulldozer track cleats. A satisfactory resolution was achieved by scarifying with a disc implement. To further ensure that previous scarifying was acceptable, several shelby tubes were pushed for samples of soil layers and a visual inspection revealed satisfactory results.

- An item was identified regarding a verification that all survey stakes are removed prior to placement of the next low perm soil layer including plugging of holes where necessary. 

BE INSTALLE AT LOCATION DETERMINED BY USRC PAIOR TO INITIATION OF ANY CONSTRUCTION ACTIVITIES WITHIN THE PERIMETER FENCE OF THE BGC. ALI

DECONTAMINATION ACTIVITIES SHALL OCCUR INSIDE THE DECONTAMINATION PAD (EXCLUSION ZOAE). PRIOR TO LEAYING THE EXCLUSION ZONE. ALL EQUIPNENT YILL BE MONI TORED FOR RADIOACTIVITY BY RCQHP PERSONNEL.

11. IF SUSPECT SOIL ANO $O$ OR CONTAMINATEO MATERIAL IS ENCOUNTERED DURING CONSTRIUCTION. THE SUBCONTRACTOR SHALL STOP WORK IMEEDIATELY IN THE VICINITY OF THE CONTAMINATED MATERIAL ANO CONTACT WSRC.

12. TEMPOAARY ACCESS ROADS FOR CONSTRUCTION, IF REQUIREO. SHALL BE INSTALLED IN LOCATIONS PREVIOUSLY APPROVED BY YSAC. AT THE COMPLETION OF THE PROJECT. THESE TEMPORARY ROADS SHALL BE REMOVED ANO THE LAND RETURNED TO APPROXIMATE ORIGINAL GRAOES TO PROVIDE POSITIVE DRAINAGE UNLESS OTHERWISE DIRECTED BY WSRC.

13. THE FUNCTIONAL CLASSIFICATION OF THE PROJECT IS GENERAL SERVICES (CS).

14. AS-BUILT GROUND ELEVATIONS AND SITE FEATURES ARE SEVENSON ENVIRONMENTAL SERYICES. INC. UNDER SUBCONTRACT OBOO127K.

DRAYING INDEX

$C-C V-E-0083$

C-CY-E-0084

$\mathrm{C}-\mathrm{CV}-\mathrm{E}-0085$

$C-C V-E-0086$

$C-C V-E-0087$

$C-C V-E-0088$

$\mathrm{C}-\mathrm{CV}-\mathrm{E}-00 \mathrm{~B}$

$C-C V-E-0090$

$\mathrm{C}-\mathrm{CV}-\mathrm{E}-00 \mathrm{gi}$

$C-C V-E-0092$

$C-C V-E-0093$

$C-C Y-F-0094$

$\mathrm{C}-\mathrm{CV}-\mathrm{E}-0095$

C-CY-E-0049

\section{C-C $-\mathrm{C}-\mathrm{E}-0049$}

$\frac{C-C V-E-0050}{C-C Y-T-005}$

$C-C 1-6-0009$

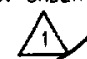

SITE VICINITY GRADING PLAN - EAST PLAN GRADING PLAN - WEST PIAN

GRADING PLAN- SOUTHWEST PLAN

ORAINAGE LAYOUT - EASI PLAN

ORAINAGE LAYOUT - WEST PLAN

OUTFALL PLAN AND ORAINAGE STRUCTURES DETAILS - 60. RCP AND $60^{\circ} \mathrm{CM}$

OUTFALL PLAN ANO DRAINAGE STRUCTURE DETAILS - 4' $\times 2$ ' $80 X$ CULVERTS

STORN ORAIN PROFILES

SECTIONS AND DETAILS

STORMHATER MANAGEMENT AND SEDIMENT CONTROL - EAST PLAN

STORMWATER MANAGEMENT AND SEOIMENT CONTROL - WEST PI AN

STORMHATER MANAGEMENT AND SEDIMENT CONTROL NOTES AND OETAILS

MWMF SOUTH SEDIMENTATION BASIN - MAINTENANCE AND IMPROVEMENTS PLAN

MWMF SOUTH SEDINENTATION BASIN - SECTIONS

MWAF SOUTH SEDIMENTATION BASIN - OETAILS AND GENERAL NOTES

\section{"Wtukivifiton: ging}
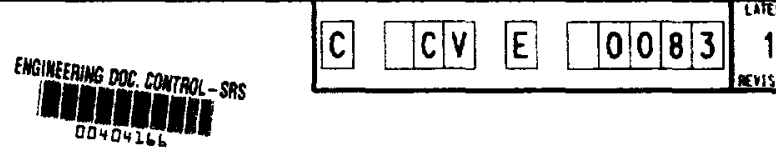

\begin{tabular}{l} 
OLD RADIOACTIVE WASTE BURIAL GROUND \\
INTERIM SOIL COVER \\
\hline
\end{tabular}




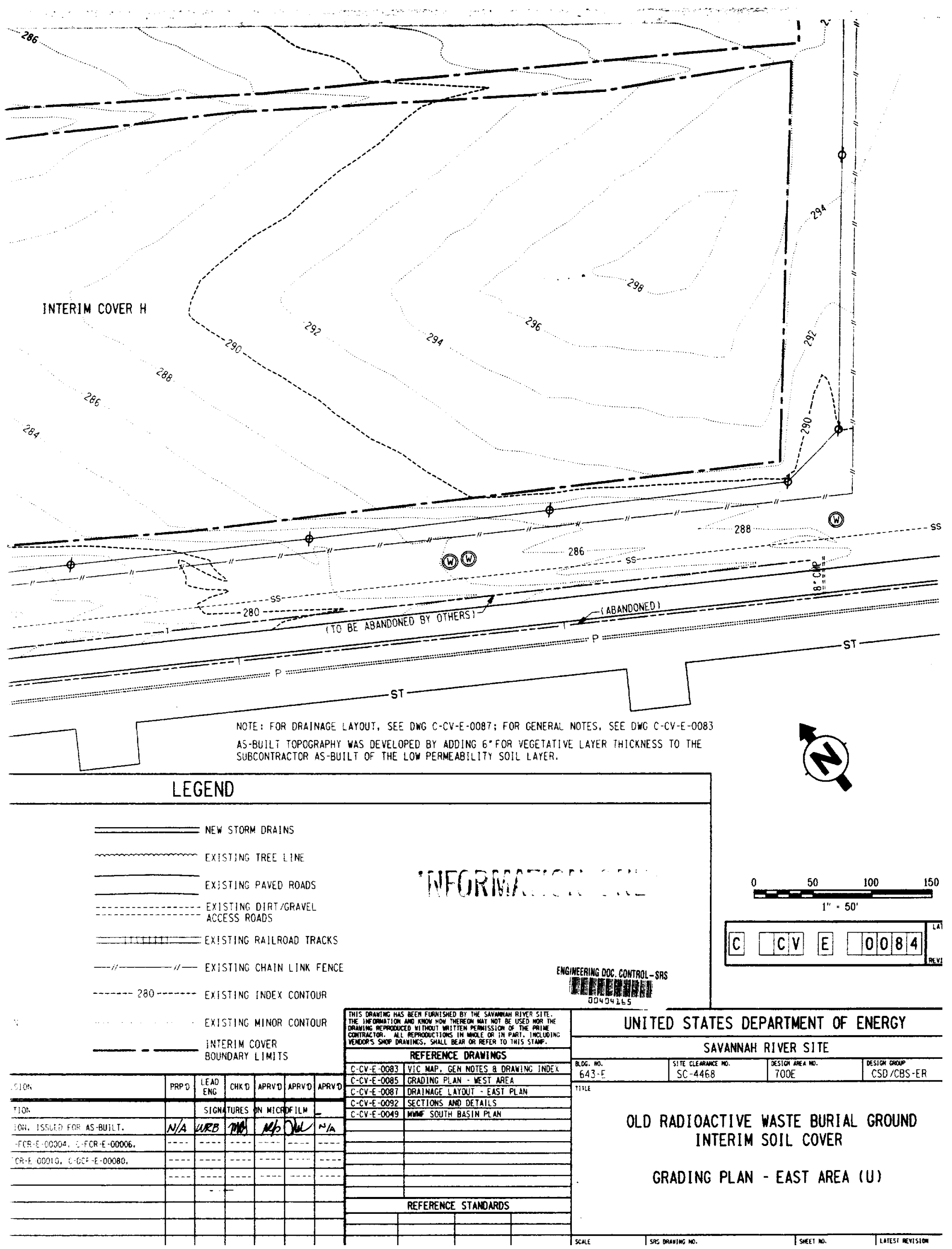




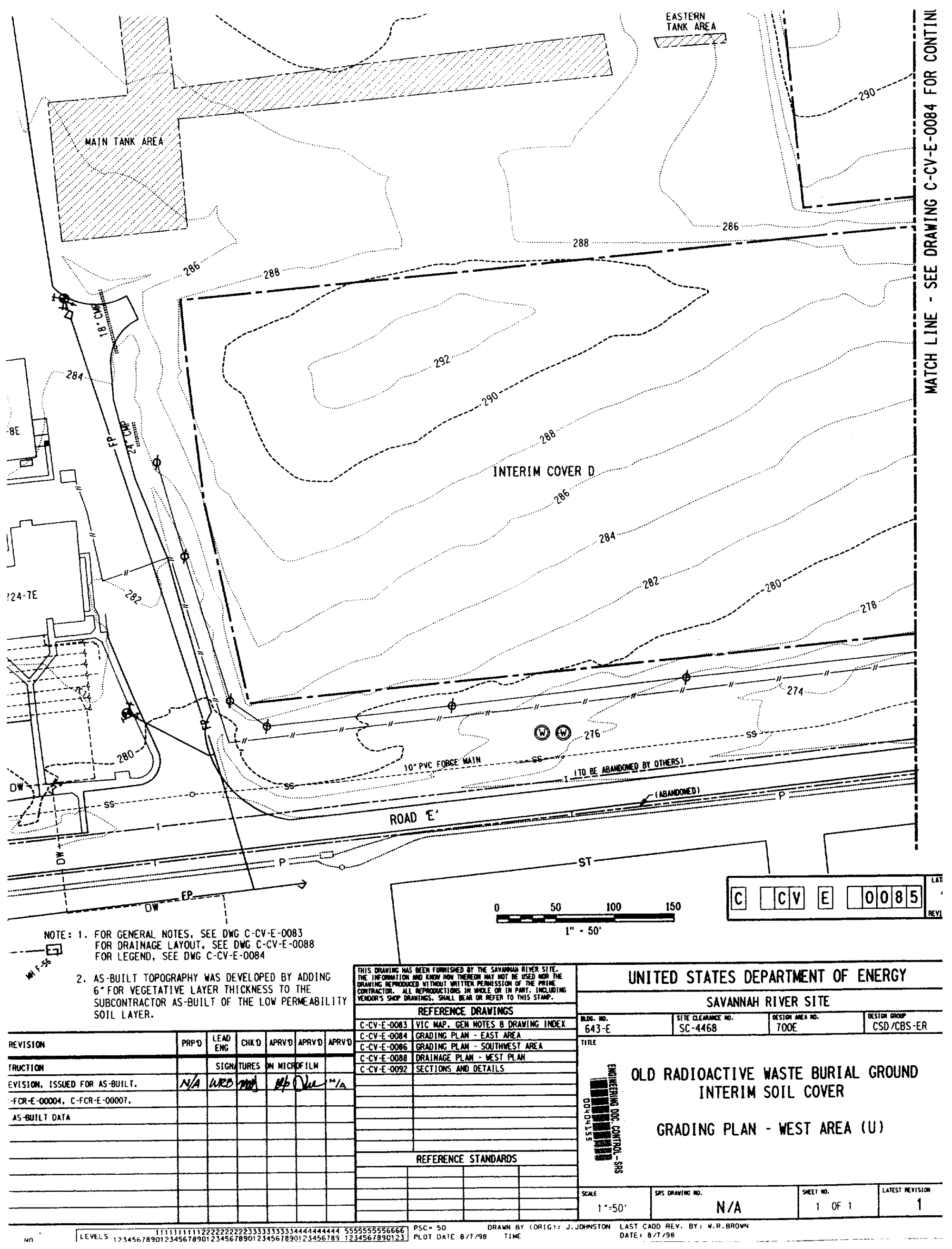


YA CMP RISEA

$-\angle S E A L$ WEL

-36" DIA CMP DUIFALL PIPE

1

UTFALL PIPE

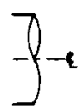
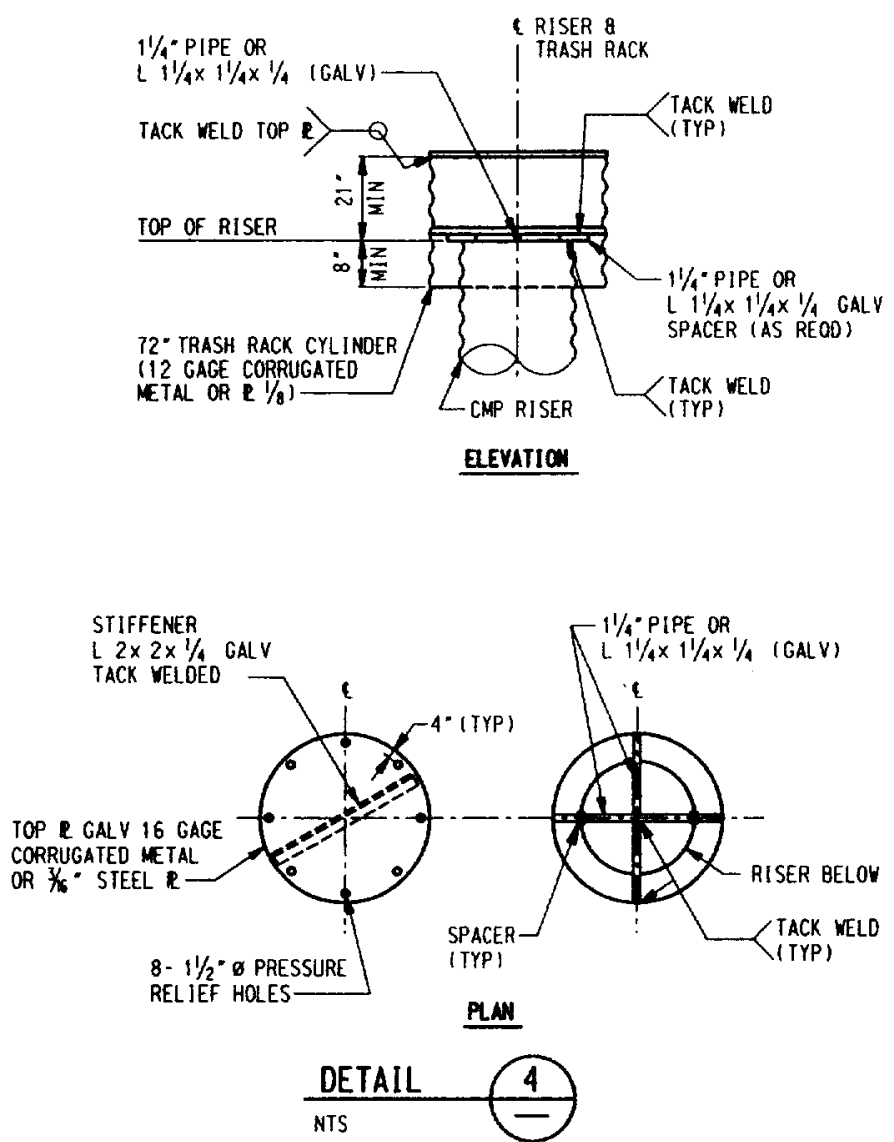

TRASH RACK AND ANTI-VORTEX DEVICE

\section{PLAN LEGEND}

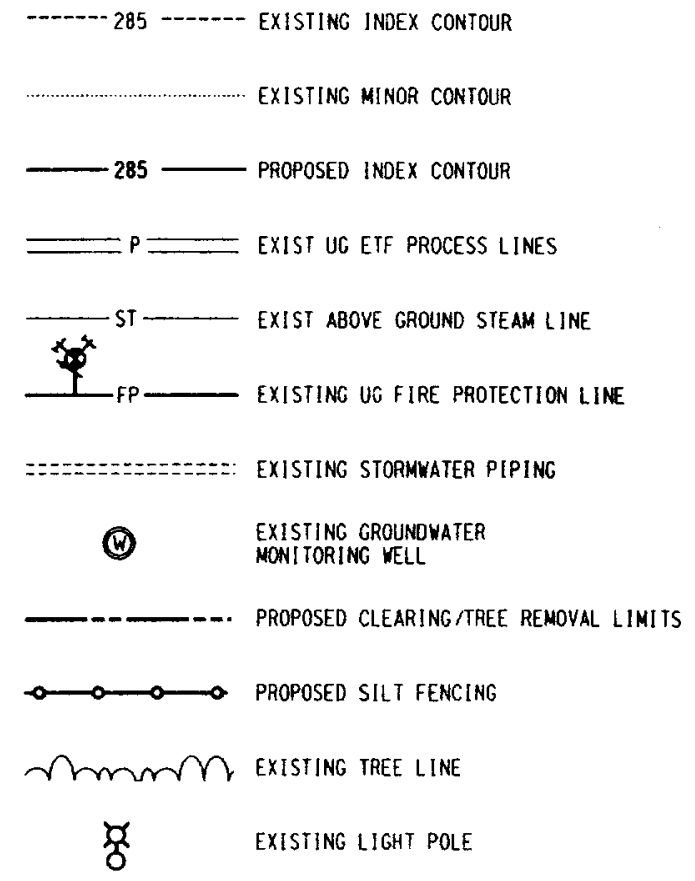

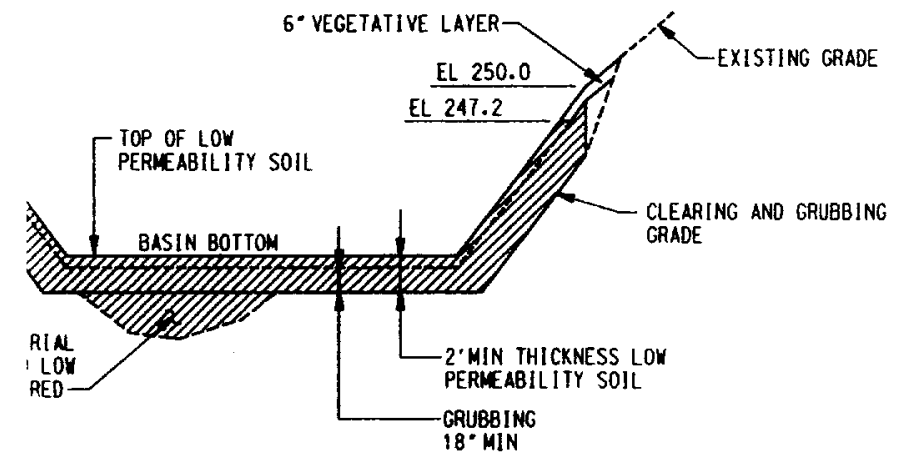

THUEST BASIN TYPICAL SECTION MTS

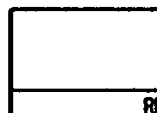
\begin{tabular}{l|l}
\hline C-CY-E-COgB & DRAINLEE LAYOUT - CESI PLA
\end{tabular} $C-C Y-E-C 091$
$C-C Y-E-C 03^{3}$ SIGA rufes W NICHOFILN N/ (1)
UNITED STATES DEPARTMENT OF ENERGY SAVANNAH RIVER SITE

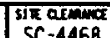
TOOE

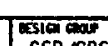

OLO RADIOACTIVE WASTE BURIAL GROUND INTERIM SOIL COVER

SOUTHWEST BASIN

STORMYATER MANAGEMENT AND SEDIMENT CONTROL GRADING, SECTIONS AND DETAILS (U)

\begin{tabular}{|c|c|}
\hline suter mo. & \\
1 of 1 & 1 \\
\hline
\end{tabular}




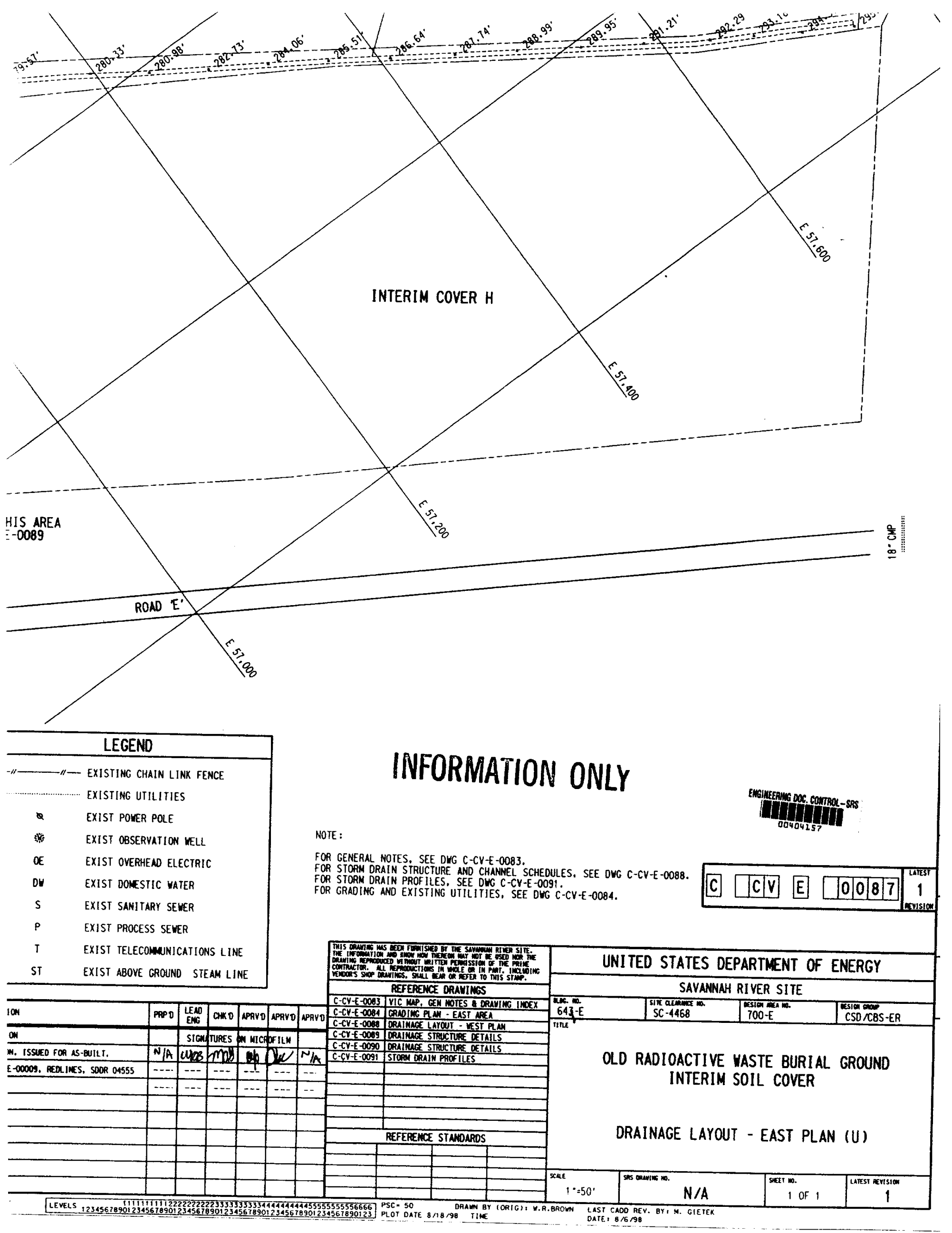




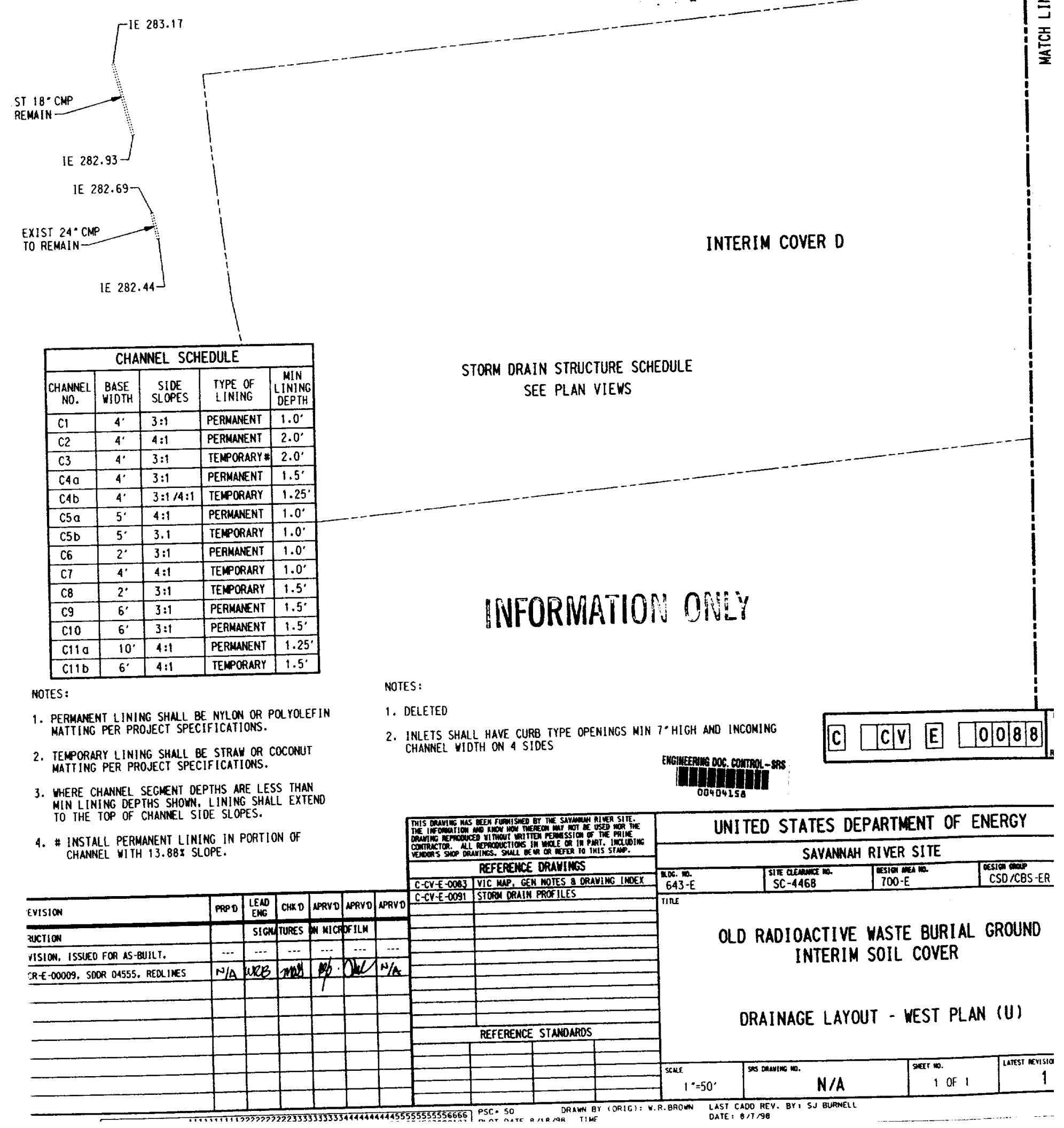




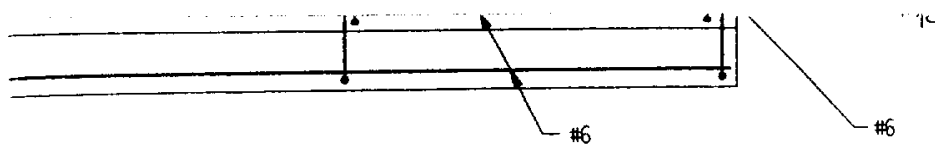

FS

- (3)
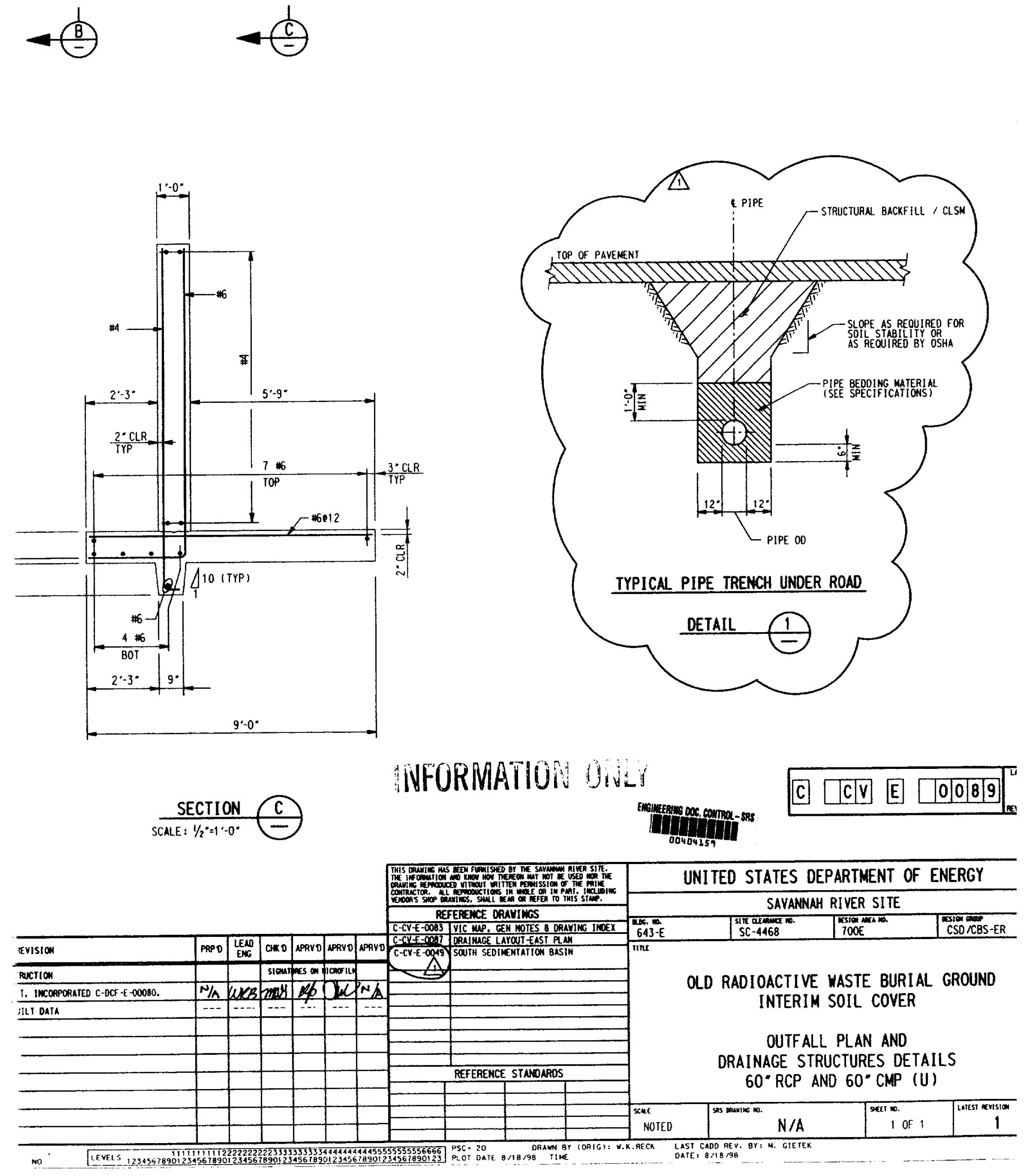

INFORMATIOU OWL 


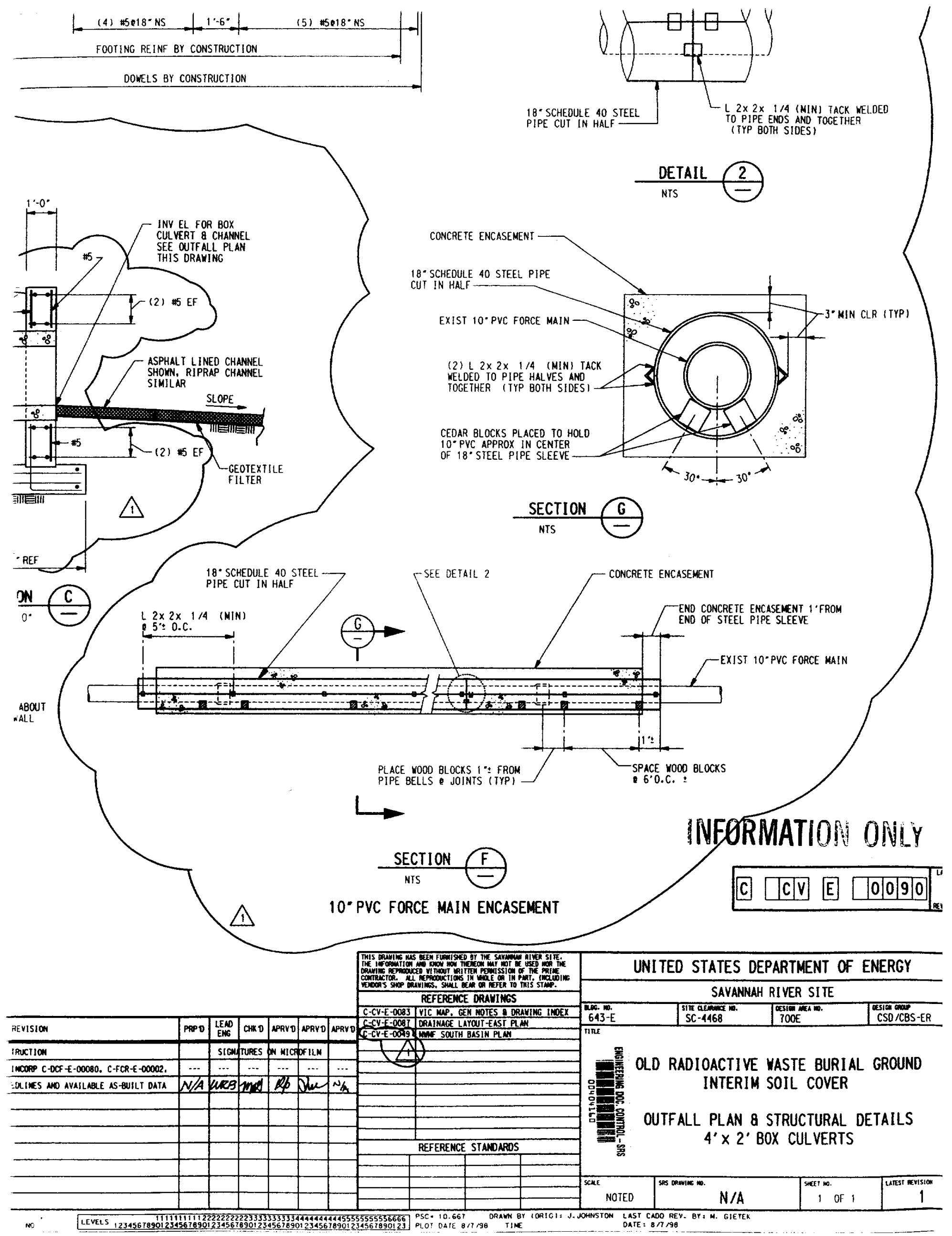




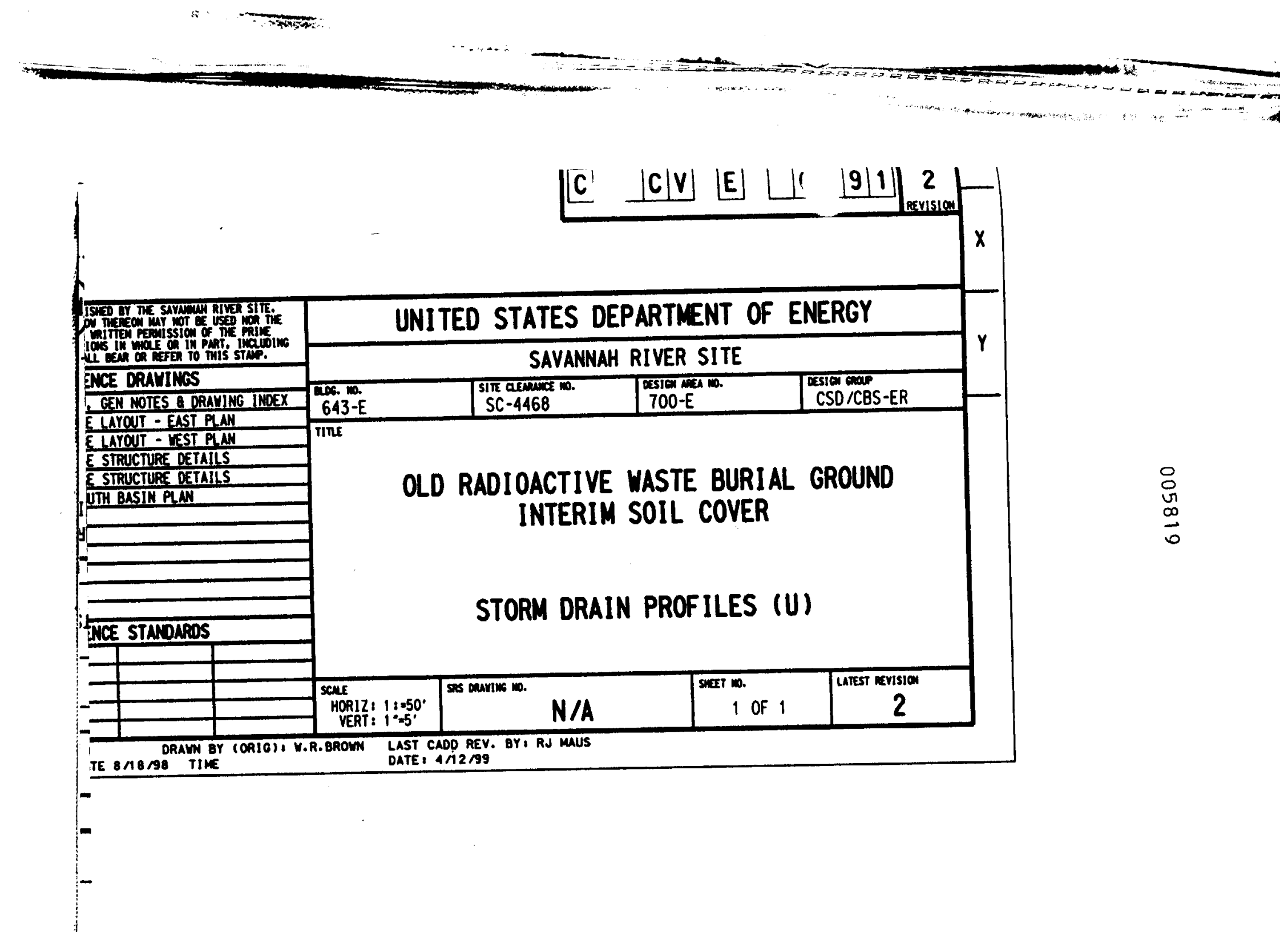




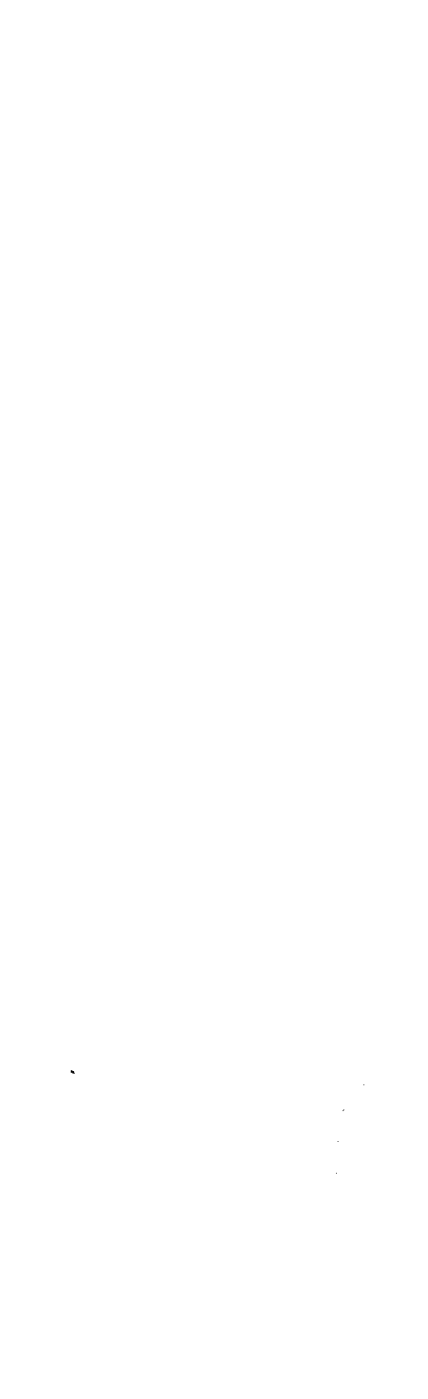

₹ GENERAL NOTES, SEE OWG C-CV-E-0083; FOR

ADING PLANS, SEE DHG C-CV-E 0084 \& C-CV-E-0085.
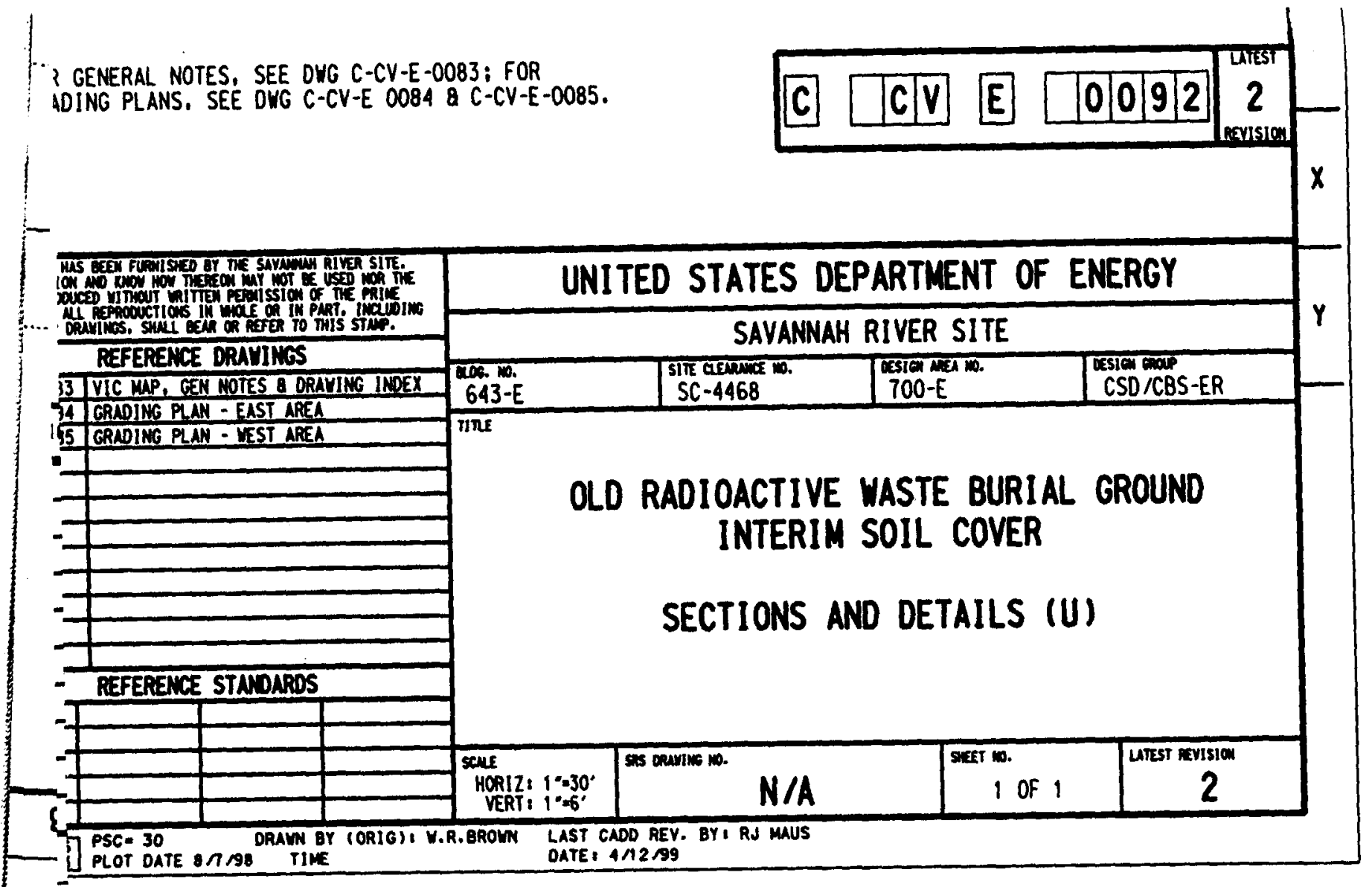


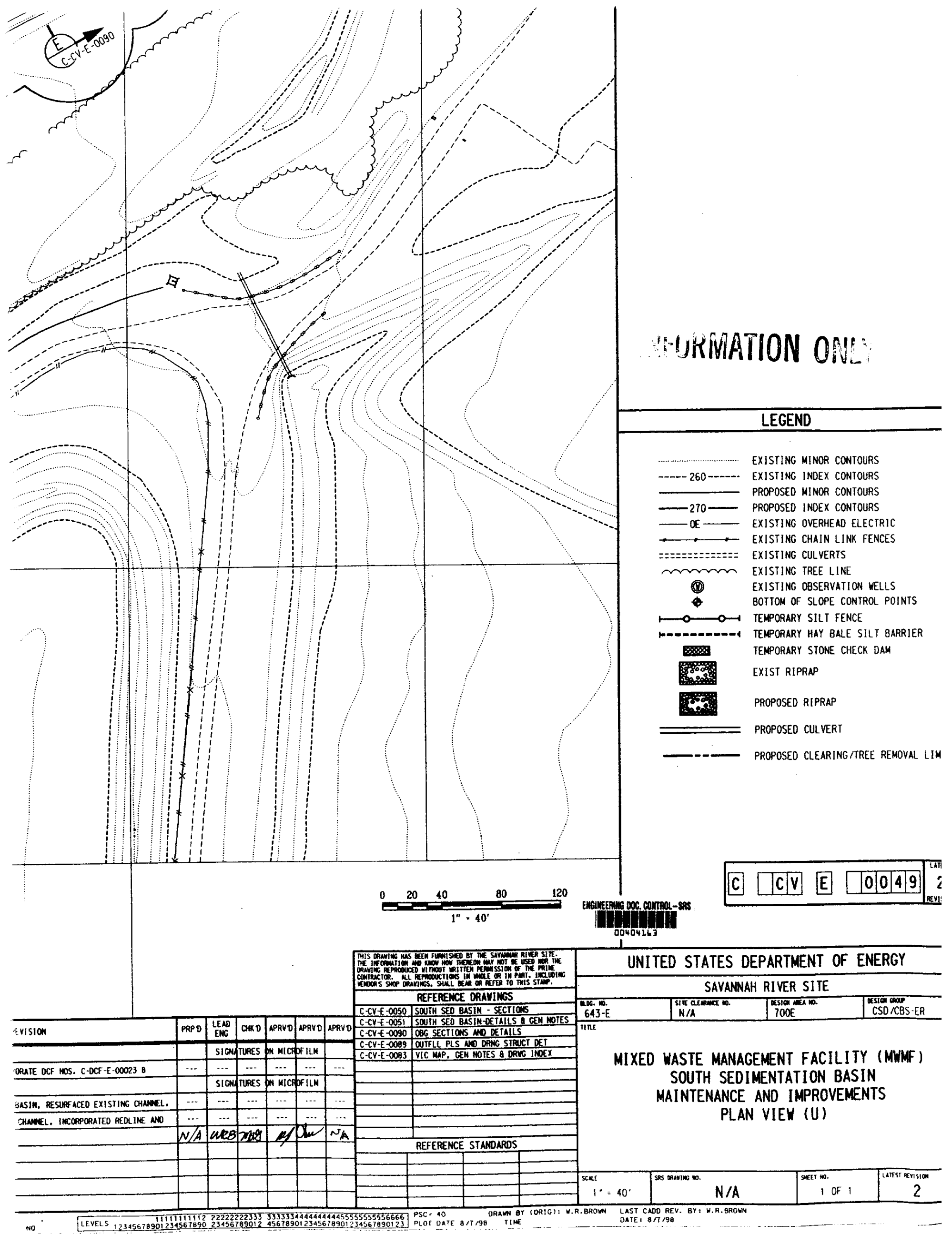




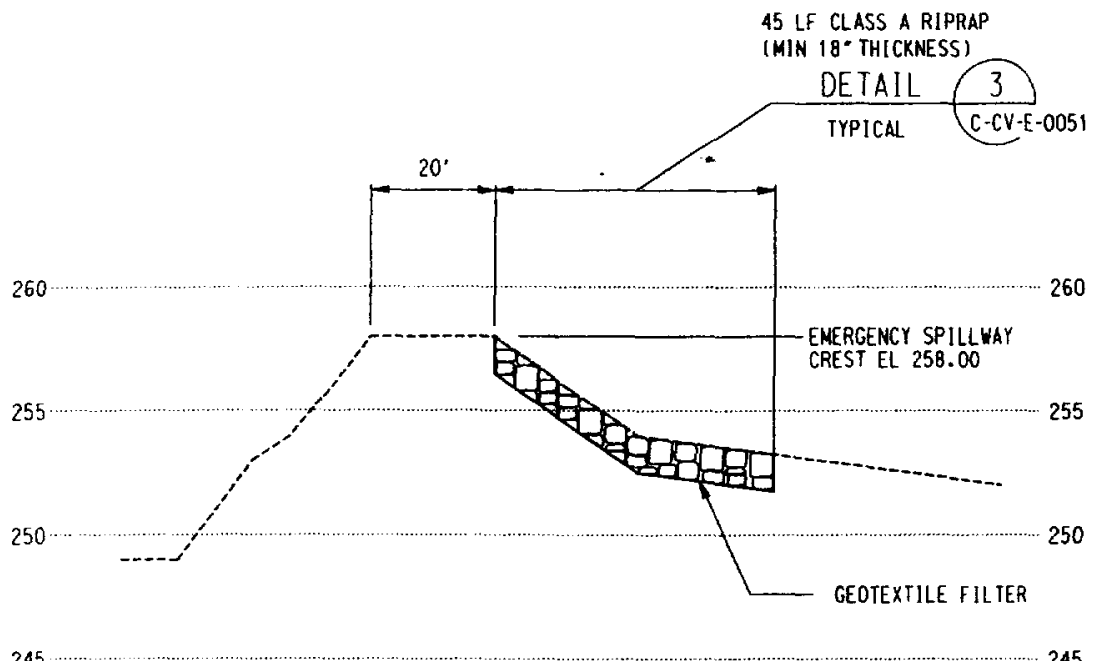

$$
245
$$

\section{SECTION B}

SCALE: HORIZ: $1^{*}=20^{\circ} \quad C-C V-E-0049$

\section{-e inmengen MHEY}

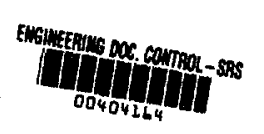

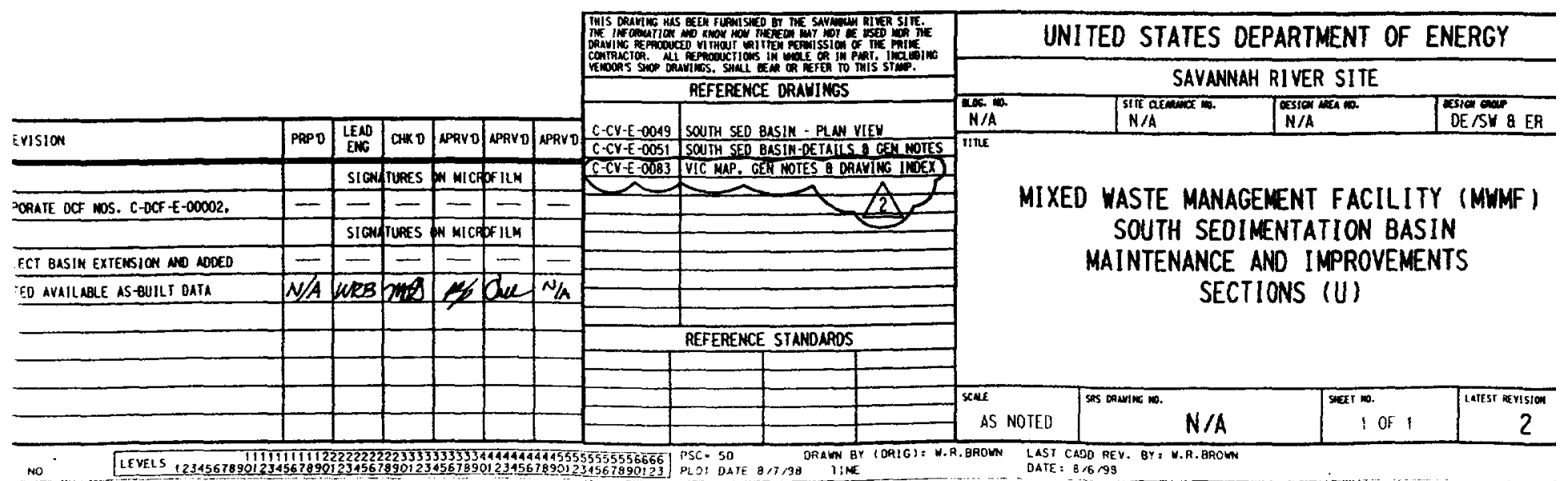

